\title{
Chapter 7. Gas transfer through clay barriers
}

\author{
Amann-Hildenbrand, A. ${ }^{1}$, Krooss, B.M. ${ }^{1}$, Harrington, J. ${ }^{2}$, \\ Cuss, R. ${ }^{2}$, Davy, ${ }^{3}{ }^{3}$, Skoczylas, F. ${ }^{3}$, Jacops, E. ${ }^{4,5,1}$, Maes, N. ${ }^{4}$
}

1. EMR | Energy and Mineral Resources Group, Institute of Geology and Geochemistry of Petroleum and Coal, Lochnerstr. 4-20, Haus B, D-52056 Aachen, Germany, Corresponding author: Alexandra Amann-Hildenbrand, Tel.: +49 (0)241 80 95752, Fax.: +49(0)241 80 92152, alexandra.amann@emr.rwth-aachen.de

2. British Geological Survey, Keyworth, Nottingham NG12 5GG, UK

3. Ecole Centrale de Lille/LML UMR CNRS 8107, Cité Scientifique, CS20048, 59651 Villeneuve d'Ascq Cedex, Fr

4. SCK・CEN, Belgian Nuclear Research Centre, Expert Group, Waste \& Disposal, Boeretang 200, 2400 Mol, Belgium. Corresponding author: Elke Jacops, Tel: +32 (0)14 333222, ejacops@sckcen.be)

5. KU Leuven, Dept. of Earth \& Environmental Sciences, Celestijnenlaan 200E, 3001 Heverlee, Belgium

\section{Introduction}

Gas transport through clay-rocks can occur by different processes that can be basically subdivided into pressure-driven flow of a bulk gas phase and transport of dissolved gas either by molecular diffusion or advective water flow (Figure 1, Marschall et al., 2005). The relative importance of these transport mechanisms depends on the boundary conditions and the scale of the system. Pressure-driven volume flow ("Darcy flow") of gas is the most efficient transport mechanism. It requires, however, pressure gradients that are sufficiently large to overcome capillary forces in the typically water-saturated rocks (purely gas-saturated argillaceous rocks are not considered in the present context). These pressure gradients may form as a consequence of the gravity field (buoyancy, compaction) or by gas generation processes (thermogenic, microbial, radiolytic). Dissolved gas may be transported by water flow along a hydraulic gradient. This process is not affected by capillary forces but constrained by the solubility of the gas. It has much lower transport efficiency than bulk gas phase flow. Molecular diffusion of dissolved gas, finally, is occurring essentially without constraints, ubiquitously and perpetually. Effective diffusion distances are, however, proportional to the square root of time, which limits the relevance of this transport process to the range of tens to hundreds of metres on a geological time scale (millions of years). 
Process understanding and the quantification of the controlling parameters, like diffusion coefficients, capillary gas breakthrough pressures and effective gas permeability coefficients, is of great importance for up-scaling purposes in different research disciplines and applications. During the past decades, gas migration through fully water-saturated geological clay-rich barriers has been investigated extensively (Thomas et al., 1968, Pusch and Forsberg, 1983; Horseman et al., 1999; Galle, 2000; Hildenbrand et al., 2002; Marschall et al., 2005; Davy et al., 2009; Harrington et al., 2009, 2012a, 2014). All of these studies aimed at the analysis of experimental data determined for different materials (rocks of different lithotype, composition, compaction state) and pressure/temperature conditions. The clay-rocks investigated in these studies, ranged from unconsolidated to indurated clays and shales, all characterised by small pores $(2-100 \mathrm{~nm})$ and very low hydraulic conductivity $\left(\mathrm{K}<10^{-12} \mathrm{~m} \cdot \mathrm{s}^{-1}\right)$ or permeability coefficients $\left(\mathrm{k}<10^{-19} \mathrm{~m}^{2}\right)$.

Studies concerning radioactive waste disposal include investigations of both the natural host rock formation and synthetic/engineered backfill material at a depth of a few hundred meters (IAEA, 2003, 2009). Within a geological disposal facility, hydrogen is generated by anaerobic corrosion of metals and through radiolysis of water (Rodwell et al., 1999; Yu and Weetjens, 2009). Additionally, methane and carbon dioxide are generated by microbial degradation of organic wastes (Rodwell et al., 1999; Ortiz et al., 2002; Johnson, 2006; Yu and Weetjens, 2009). The focus of carbon capture and storage (CCS) studies is on the analysis of the longterm sealing efficiency of lithologies above depleted reservoirs or saline aquifers, typically at larger depths (hundreds to thousands of meters). During the last decade, several studies were published on the sealing integrity of clay-rocks to carbon dioxide (Hildenbrand et al., 2004; Li et al., 2005; Hangx et al., 2009; Harrington et al., 2009; Skurtveit et al., 2012; AmannHildenbrand et al., 2013). In the context of petroleum system analysis, a significant volume of research has been undertaken regarding gas/oil expulsion mechanisms from sources rocks during burial history (Tissot \& Pellet, 1971; Appold \& Nunn, 2002), secondary migration (Luo et al., 2008) and the capillary sealing capacity of caprocks overlying natural gas accumulations (Berg, 1975; Schowalter, 1979; Krooss, 1992; Schlömer and Kross, 2004; Li et al., 2005; Berne et al., 2010). Recently, more attention has been paid to investigations of the transport efficiency of shales in the context of oil/gas shale production (Bustin et al., 2008; Eseme et al., 2012; Amann-Hildenbrand et al., 2012; Ghanizadeh et al., 2013, 2014). Analysis of the migration mechanisms within partly unlithified strata becomes important when explaining the 
origin of overpressure zones, sub-seafloor gas domes and gas seepages (Hovland \& Judd, 1988; Boudreau, 2012).

The conduction of experiments and data evaluation/interpretation requires a profound process understanding and a high level of experience. The acquisition and preparation of adequate samples for laboratory experiments usually constitutes a major challenge and may have serious impact on the representativeness of the experimental results. Information on the success/failure rate of the sample preparation procedure should therefore be provided. Sample specimens "surviving" this procedure are subjected to various experimental protocols to derive information on their gas transport properties.

The present overview first presents the theoretical background of gas diffusion and advective flow, each followed by a literature review (sections 2 and 3). Different experimental methods are described in sections 4.1 and 4.2. Details are provided on selected experiments performed at the Belgian Nuclear Research Centre (SCK-CEN, Belgium), Ecole Centrale de Lille (France), British Geological Survey (UK), and at RWTH-Aachen University (Germany) (section 4.3). Experimental data are discussed with respect to different petrophysical parameters outlined above: i) gas diffusion, ii) evolution of gas breakthrough, iii) dilation-controlled flow, and iv) effective gas permeability after breakthrough. These experiments were conducted under different pressure and temperature conditions, depending on sample type, burial depth and research focus (e.g. radioactive waste disposal, natural gas exploration, or carbon dioxide storage). The interpretation of the experimental results can be difficult and sometimes a clear discrimination between different mechanisms (and the controlling parameters) is not possible. This holds, for instance, for gas breakthrough experiments where the observed transport can be interpreted as intermittent, continuous, capillary- or dilation-controlled flow. Also, low gas flow rates through samples on the length-scale of centimetres can be equally explained by effective two-phase flow or diffusion of dissolved gas. 


\section{Diffusive transport of gas in solution}

\subsection{Theoretical background}

\subsubsection{General description of diffusion}

Diffusion is a mass transport due to the random thermal motion of particles of molecular size (atoms, molecules, ions). This process can be represented by a molecular random walk, known as the Brownian motion. Diffusion causes a molecular flux along a concentration gradient and increases the spreading of a concentration front or peak with time. The random motion of particles results in increasing entropy (Grathwohl, 1998).

Fick's first law of diffusion relates the diffusive flux $F\left(\mathrm{~mol} \cdot \mathrm{m}^{-2} \cdot \mathrm{s}^{-1}\right)$ to the concentration gradient $\partial C / \partial x($ Crank, 1975):

$\boldsymbol{F}=-\boldsymbol{D} \frac{\partial C}{\partial x}$

$D$ denotes the diffusion coefficient $\left(\mathrm{m}^{2} \cdot \mathrm{s}^{-1}\right)$, which is a measure for mobility of the particles, C is the concentration $\left(\mathrm{mol} \cdot \mathrm{m}^{-3}\right.$ ) and $\mathrm{x}$ is the position $(\mathrm{m})$. The mass conservation equation

$\frac{\partial C}{\partial t}=D \frac{\partial^{2} C}{\partial^{2} x}$

is commonly termed Fick's second law of diffusion, where $t$ is time (s).

\subsubsection{Gas diffusion in water}

Gases dissolve in liquids to different extents. Henry's Law (Mackay and Shiu, 1981) states that at a constant temperature, the amount of a given gas that dissolves in a given type and volume of liquid is directly proportional to the partial pressure $p_{i}$ of that gas in equilibrium with that liquid:

$p_{i}=k_{H} C_{i \_l i q u i d}$

Here, $C_{i_{-} \text {liquid }}$ is the concentration of the dissolved gas phase in the liquid and $k_{H}$ is the Henry constant. Various other formulations of Henry's law exist and attention should be paid to the selection of the correct units and parameters. Henry's law is a limiting law valid for low partial pressures $(<0.5-1 \mathrm{MPa})$ and solubility values below $3 \mathrm{~mol} \%$. At very high pressures the relationship between the gas partial pressure and the concentration of the dissolved gas is no longer linear (Prausnitz et al., 1999). 


\subsubsection{Gas diffusion in porous media}

Under the influence of a concentration gradient a net diffusive flux of the dissolved gas will occur. The diffusion coefficient of dissolved gas in bulk water or bulk aqueous solution is denoted as $D_{0}$. Experimental values for $D_{0}$ are available in the literature (c.f. Boudreau, 1996)

Diffusion of gas in water-saturated porous media is described in the literature in different ways (Krooss, 1992; Horseman et al., 1996; Berne et al., 2010). The reader is therefore advised to check the individual definitions before using published diffusion coefficients. Terms and definitions used in this chapter are outlined below.

The diffusive flux of a gas (i) in a water-saturated porous medium with porosity $\phi$ can be described in terms of the effective diffusion coefficient $\left(D_{\text {eff }}\right)$.

$F=-D_{\text {eff }} \frac{\partial c_{i_{\text {bulk_rock }}}}{\partial x}$

Here the porous medium is treated as a macroscopically homogeneous material and $C_{i_{-} \text {bulk_rock }}$ is the "bulk rock" volume concentration in a representative element of volume (REV) of this material. If the gas is only present in the dissolved state in the pore water (no adsorption on mineral surfaces or organic matter) the bulk volume concentration is:

$C_{i_{-} \text {bulk_rock }}=\phi \cdot C_{i_{\text {_liquid }}}$

Fick's first law is then re-written as:

$F=-D_{\text {eff }} \frac{\partial c_{i_{\text {bulk_rock }}}}{\partial x}=-\phi * D_{\text {eff }} \frac{\partial C_{\text {illiquid }}}{\partial x}$

Here $D_{p}$ is the "pore diffusion coefficient" that contains the effects of the pore structure on the molecular diffusion process. These effects comprise the narrowing (constriction) of transport pathways (constrictivity $\delta$ ) due to pore throats and the increased length of the effective transport path $\left(I_{t p}\right)$ relative to the Euclidian distance $(l)$ between two positions in the porous medium (tortuosity $\tau=l_{t p} / l$ ). The "pore diffusion coefficient" is commonly defined as:

$D_{p}=D_{0} \delta / \tau^{2}$

It is thus related to the effective and the bulk fluid diffusion coefficients according to:

$D_{\text {eff }}=D_{0} \phi \delta / \tau^{2}=D_{p} \phi$ 
It is evident from Equation 6 that for the calculation of diffusive transport $D_{\text {eff }}$ has to be used in combination with the bulk rock concentration gradient whereas $D_{p}$ and $D_{0}$ have to be used in combination with the liquid phase concentration gradient.

Apart from constrictivity and tortuosity the diffusion of molecules through porous media (rocks) can be retarded by physico-chemical interactions with mineral or organic matrix components. These effects involving reversible (ad-/desorption, precipitation/dissolution) and irreversible (chemisorption, reaction) effects can be taken into account by introducing the "apparent diffusion coefficient" $\left(D_{a p p}=D_{p} / R\right)$ where $R$ is retardation factor (Bruggeman et al., 2009; Jacops et al., 2013).

\subsection{Literature review}

Diffusive transport of gas through water-saturated rocks on the length-scales of geological systems $(>10 \mathrm{~m})$ has only a very low transport capacity as compared to convective (pressuredriven) transport (Krooss, 1992). However diffusion may become the dominant transport mechanism on the $10-1000 \mathrm{~m}$ scale if there is no pressure driven volume flow over extended periods of geological time. Relevant distances for diffusive transport may be estimated using the relationship:

$\frac{D_{e f f} \cdot t}{l^{2}}=0.1$

Thus, for an effective diffusion coefficient of $10^{-10} \mathrm{~m}^{2} \cdot \mathrm{s}^{-1}$ and a diffusion time of $1 \mathrm{Ma}$ the diffusion distance is in the range of $200 \mathrm{~m}(177.6 \mathrm{~m})$.

During the past decades research on diffusion in geological systems was mainly focused on three topics:

- The role of diffusion in primary migration of petroleum, i.e. transport of gas/oil within source rocks and expulsion from these source rocks (Leythaeuser et al., 1982; Krooss, 1988; Thomas and Clouse, 1990a,b,c; Stainforth and Reinders, 1990)

- Losses from natural gas reservoirs through clay overburden/caprocks (Antonov P. L. et al., 1958; Stklyanin et al., 1968; Stklyanin and Litvinova, 1971; Nesterow and Uschatinskij, 1972; Price et al., 1981; Leythaeuser et al., 1982; Krooss and Leythaeuser, 1988; Krooss et al., 1992a, b; Schlömer and Krooss, 1997)

- Long-term safety of natural and geo-engineered barriers, i.e. (radioactive) waste disposal (Horseman et al., 1996) 
Factors influencing the effective diffusion coefficients, such as temperature, tortuosity/constrictivity and retardation effects of the geologic medium have been widely discussed in the literature. Table 1 lists published diffusion coefficients for gases in watersaturated rocks of different lithotypes and at different temperatures.

Diffusion coefficients in pure water and brines $\left(D_{0}\right)$ can be considered as baseline values for diffusion in water-saturated sediments and sedimentary rocks (Horseman et al., 1996). While $D_{0}$ values range from approximately $10^{-9} \mathrm{~m}^{2} \cdot \mathrm{s}^{-1} \mathrm{~s}^{-1}$ at $0^{\circ} \mathrm{C}$ to $10^{-8} \mathrm{~m}^{2} \cdot \mathrm{s}^{-1} \mathrm{~s}^{-1}$ at $160^{\circ} \mathrm{C}$ (Wilke and Chang, 1955; Ferrell and Himmelblau, 1967), effective diffusion coefficients in sedimentary rocks are lower by one to three orders of magnitudes (Krooss, 1992). This decrease in diffusivity is attributed to the tortuosity and constrictivity of the transport pore system and/or the interaction of the diffusing gas with mineral surfaces and the organic matter of carbonaceous rocks. Schlömer and Krooss (2004) showed that an increase of effective stress from 10 to $40 \mathrm{MPa}$ resulted in a decrease of the effective diffusion coefficients of sedimentary rocks by 30 to $40 \%$. Thomas and Clouse $(1990 a$, b) attributed enhanced diffusive fluxes of hydrocarbon gases through cores with organic coatings to the higher solubility of hydrocarbons in the organic coating, i.e. increased bulk concentration gradient. Effective diffusion coefficients of coated and uncoated samples were similar indicating that the enhanced diffusive flux was not due to an increase in molecular mobility of the diffusing species but to a higher bulk volume concentration resulting from the organic coating. This would in consequence lead to a higher transport capacity. Several studies have documented that effective diffusion coefficients of hydrocarbon gases in sedimentary rocks decrease with increasing organic carbon (TOC) contents (Schlömer and Krooss, 1997, 2004; Zhang and Krooss, 2001). This is attributed to retardation effects by adsorption of gas on/in dispersed organic material, which is more pronounced for methane than for nitrogen. As adsorption capacity decreases with increasing temperature, the retardation effect is reduced and effective diffusion coefficients increase. Additionally, it was found that diffusion results in an isotopic fractionation of the gases, due to the different mobility of the diffusing isotopic species $\left(D_{\text {eff }}\right)$. Solubility fractionation was found to be negligible (Zhang and Krooss, 2001; Schlömer and Krooss, 2004). The diffused methane was significantly depleted in the heavier carbon isotope species $\left({ }^{13} \mathrm{C}\right)$, especially during the initial non-stationary state. The effect was larger for shale samples with higher TOC contents. 
Diffusion experiments with $\mathrm{CO}_{2}$ on sedimentary rocks provided hints that the pore morphology of the rock samples changed in the course of repetitive tests. For a shale and marlstone, Busch et al. (2008) and Wollenweber et al. (2010) observed an increase of effective diffusion coefficient by a factor of 1.6 and 6.5 , respectively. This was attributed to irreversible alteration of the pore system by mineral reactions or sorptive $\mathrm{CO}_{2}$ uptake resulting in a retardation effect during the first diffusion test. In the subsequent experiments, the reactivity of the rock samples was obviously reduced as indicated by reduced bulk $\mathrm{CO}_{2}$ volume equilibrium concentrations and higher effective diffusion coefficients (Busch et al., 2008).

In the context of radioactive waste disposal in clay host rocks, the relative generation and transport rates of molecular hydrogen $\left(\mathrm{H}_{2}\right)$ are important parameter for the estimation of pressure build-up. The availability of diffusion coefficients for $\mathrm{H}_{2}$ in water-saturated clays/clayrocks required for these calculations is still very limited. Due to the experimental difficulties associated with the determination of $\mathrm{H}_{2}$ diffusion coefficients (Volckaert et al., 1995; Ortiz et al., 2002; Didier, 2012; Jacops et al., 2013), the diffusion coefficients of He are often used as a first approximation. Recently, significant progress has been made in the determination of reliable diffusion coefficients for $\mathrm{H}_{2}$ in clay-rocks and shales (Jacops et al., 2013).

\section{Advective flow}

\subsection{Theoretical background}

\subsubsection{Single-phase viscous flow (Darcy flow)}

Apart from the diffusional process, viscous pressure-driven transport of the gas specimen must be considered. In a fully water saturated porous medium, dissolved gas molecules may be dragged along with the water flood. Transport is described by Darcy's law for incompressible media, relating the flux $\left(Q, \mathrm{~m}^{3} \cdot \mathrm{s}^{-1}\right)$ to the absolute or intrinsic permeability coefficient $\left(k, m^{2}\right)$, fluid viscosity $(\mu, \mathrm{Pa} \cdot \mathrm{s})$, and the pressure gradient $(\Delta \mathrm{p} / \Delta \mathrm{x}, \mathrm{Pa})$ :

$Q=-\frac{k}{\eta} \cdot A \cdot \frac{\Delta p}{\Delta x}$

The parameter $\mathrm{k}$ represents a characteristic parameter of the rock specimen.

In hydrologic applications the pressure difference $\Delta \mathrm{p}$ is substituted by the hydraulic head $(\Delta \mathrm{h})$, which is the water pressure equivalent to the height of a static water column: 


$$
\Delta h=\frac{\Delta p}{\rho_{\text {water }} \cdot g}
$$

In this context the hydraulic conductivity $(\mathrm{K}, \mathrm{m} / \mathrm{s})$ is calculated by

$$
Q=-K \cdot A \cdot \frac{\Delta h}{\Delta x}
$$

Assuming a water density and viscosity of approximately $1000 \mathrm{~kg} / \mathrm{m}^{3}$ and $1000 \mu \mathrm{Pa} \cdot \mathrm{s}$, the relationship between hydraulic conductivity, $\mathrm{K}$, and intrinsic permeability, $\mathrm{k}$, is approximately $\mathrm{K} \sim \mathrm{k} \cdot 10^{7}$.

In the case of a completely dry material, flow of the gas phase is described by an integrated form of Darcy's law, which accounts for the compressibility of the gas phase. The conventional volume-based form is converted to a mass-based form using the ideal gas law, where the amount of mass (dn) moving through the sample is calculated from either the volume (dV) or pressure $(\mathrm{dp})$ change with time.

$$
\frac{d n}{d t}=\frac{p_{2}}{R \cdot T} \frac{d V_{2}}{d t}=\frac{V_{2}}{R \cdot T} \frac{d p_{2}}{d t}=-\frac{k_{g a s} \cdot A}{\mu \cdot R \cdot T} \frac{\left(p_{2}^{2}-p_{1}^{2}\right)}{2 \cdot d x}
$$

$p_{1}$ and $p_{2}$ are the pressures on the up and downstream pressure side of the rock specimen, $k_{\text {gas }}\left(m^{2}\right)$ is the apparent gas permeability at given mean pressure, $\left(p_{1}+p_{2}\right) / 2$.

To yield the absolute/intrinsic permeability of the rock one is usually accounting for the slipflow effect or Knudsen diffusion, which is related to the pressure and temperature dependent mean free path of the gas molecules. Gas permeability increases linearly with the reciprocal mean pressure, as more gas molecules collide with the pore walls. Extrapolation of the apparent gas permeabilities to infinite high mean gas pressure yields the infinite gas permeability, $k_{\text {inf_gas, }}$ which equals the intrinsic permeability of the porous medium, $k$, in the absence of electroosmotic counter-pressures (Klinkenberg, 1941; Weber \& Stanjek, 2012).

\subsubsection{Two-phase fluid system}

Separate gas flow is controlled by two processes:

1. Visco-capillary two-phase flow: this is represented by gas flow within the original porosity by the displacement of pore water by the gas resulting in desaturation of the rock matrix. As gas pressure increases, water is displaced from successively smaller pores. Desaturation of the rock matrix results in a corresponding increase in gas conductivity and the likelihood of capillary failure is increased. 
2. Dilatant flow: upon mechanical failure of the pore network, gas flow occurs along pressure induced pathways along previous or re-activated fractures on the microand macro-scale (tensile fracturing) or within the matrix by 'dilatancy' (opening/closure of pores).

However, the movement of gas is a dynamic process. When gas pressure drops below a critical value (often referred to as the capillary threshold pressure), advective gas flow ceases. Similarly, changes in effective stress or re-saturation of the medium with water, can result in a reduction, or even a cessation, of gas flow (Hildenbrand et al., 2003; Davy et al., 2012, 2013; Liu et al., 2012).

\section{Capillary pressure controlled desaturation, drainage/imbibition}

The effective saturation and distribution of each phase within a rigid porous medium is generally associated with capillary effects, i.e. the actual pore size distribution, fluid pressures and wetting characteristics (interfacial tension \& contact angles). The Washburn or the YoungLaplace equation (Washburn, 1921; Dullien, 1979) describes the relationship between the (excess) capillary pressure $\left(p_{c}\right)$ and the pore radius $(r)$ which are intruded by the non-wetting phase:

$\boldsymbol{p}_{c}=\boldsymbol{p}_{n w}-\boldsymbol{p}_{w}=2 \gamma \cos \theta / r$

Here $\gamma$ is the liquid/gas interfacial tension $\left(\mathrm{Nm}^{-1}\right)$, and the wetting angle $\theta$ (degrees) and $r$ is the radius $(m)$ of an ideal cylindrical pore.

This equation can be used to describe the pure capillary controlled invasion of a non-wetting (gas) phase into a fully water saturated medium (Figure 2). Considering the gas pressure to increase up to a critical gas/water pressure difference $\left(p_{n w}-p_{w}\right)$, the capillary entry pressure $\left(p_{c_{-} \text {entry }}\right)$, the gas phase starts to displace water from the pore system. Upon further gas pressure increase the system will successively be drained, where the gas phase displaces the wetting phase from successively smaller pores. When finally a continuous non-wetting phase (backbone) developed along the pore network, viscous gas flow is initiated (threshold or breakthrough pressure, $\left.p_{c_{\_} b r t h r}\right)$. Higher capillary pressures lead to further desaturation and corresponding higher gas flow rates until maximum desaturation (irreducible water saturation). A decrease in capillary pressure leads to the re-imbibition of water, successively reducing the non-wetting phase connecting pathways until flow stops (final snap-off pressure, $\mathrm{p}_{\mathrm{c}_{-} \text {snap-off, }}$ or shut-in pressure). Trapped amounts of the non-wetting phase within the pore 
network lead to a saturation hysteresis between the first drainage and imbibition process as well as after successive drainage/imbibition cycles (repetitive gas pressure build up, gas pressure release and decrease).

Upon desaturation, the porous medium contains two immiscible fluids, water and gas phase, each at a different saturation. Here, one distinguishes between wetting and non-wetting fluids. The extent to which the fluids are in contact with the pore walls is determined by the interfacial tension, $\gamma$, between the fluid phases (solid, liquid, gas) and the contact angle, $\theta$, (measured in the denser fluid phase). Generally, wetting fluids occupy the smallest pores and are in direct contact with the pore walls. Non-wetting fluids tend to minimize its contact area with the pore walls. Usually, the mineral phases are considered water wet, with water being the wetting fluid (Schowalter, 1979; Pentland, 2010). However, rocks may be of intermediate wettability, depending on its different compounds or surface contaminations, e.g. mineral phases and organic compounds within the rock matrix, or the type of gas, and their geologic evolution (Honapour et al., 1987; Borysenko et al., 2009; Bikkina, 2011).

Two different types of immiscible fluid systems are known: (1) both fluid phases progress simultaneously through all capillary paths (funicular flow), where the wetting fluid remains in contact with the solid pore walls, and (2) the separate channel flow concept, where each fluid progresses through its own interconnected paths (Dullien, 1992; Scheidegger, 1974; Qingjie et al., 2002). In practice, two-phase flow through a pore network is a combination of the above two processes.

The hysteresis phenomenon is related to two different processes: water retention within the pore network by capillary forces and adsorption (Daïan, 2010; M'Jahad, 2012). The first desaturation cycle (drainage) can be described by (1) the initial viscous water displacement, ending at the irreducible water saturation, and finally (2) by desorption down to (theoretically) full drying. Upon re-saturation (imbibition), natural porous materials do not regain the same water saturation. This phenomenon is given independent of the type of resaturation, i.e. change of capillary pressure $\left(p_{n w}-p_{w}\right)$ or relative humidity $\mathrm{RH}$ (relative water vapor pressure, $p_{\text {partial }} / p_{\text {saturation }}$ ) and is associated with the complex arrangement of small pore throats and larger pore bodies (Diamond, 2000; Espinosa et al., 2006; Ishida et al., 2007). During re-saturation non-wetting phase bubbles are trapped within the pore space due to the existence of small pore throats, due to the so called bottle neck effect (snap-off) (Kleppe et al., 
1997; Diamond, 2000; Luo et al., 2008). Therefore, water saturation is larger during first desaturation than along any subsequent drainage/imbibition process.

\section{Effective/relative gas permeability}

In a two-phase fluid system both, saturation and permeability to each fluid phase (i), will change as function of the capillary pressure. By definition, the conductivity of each phase depends on the prevailing fluid saturation. One does no longer consider permeability to be a characteristic rock property. Instead, each fluid phase is characterised by an effective permeability $\left(\mathrm{k}_{\text {eff_i }}\right)$ as function of its saturation $\left(\mathrm{S}_{\mathrm{i}}\right)$. Normalized to the intrinsic permeability, $k$, the conductivity to each phase is expressed by its relative permeability $\left(\mathrm{k}_{\mathrm{ri}}\right)$. In general, multiphase fluid flow is modelled by combining the continuity equation for each phase with the generalised form of Darcy's law and constitutive equations for relative permeabilities and capillary pressures between phases (Parker, 1989). The continuity equation for each phase may be written as

$$
\frac{\partial}{\partial t}\left(\phi \rho_{i} S_{i}\right)+\nabla \cdot\left(\rho_{i} \boldsymbol{q}_{i}\right)=\gamma_{i}
$$

where $\phi$ is the medium porosity, $\rho_{i}$ is the phase density for phase $i, S_{i}$ is the saturation of phase $i, q_{i}$ is the Darcy velocity vector for phase $i$, and $\gamma_{i}$ is a source-sink term for mass transfer between the phases and any external sources. Darcy's law for phase i may be written as

$$
\boldsymbol{q}_{i}=-\frac{k_{r i} \boldsymbol{k}}{\eta_{i}} \nabla\left(p_{i}+\rho_{i} g z\right)
$$

where $k_{r i}$ is the relative permeability of phase $i, k$ is the intrinsic permeability tensor, $\eta_{i}$ is the dynamic viscosity of phase $i, p_{i}$ is the pressure in phase $i$, and $g$ is the acceleration due to gravity. To complete the description of the system it is necessary to define the relative permeabilities and capillary pressures as functions of the phase saturations (e.g. Honapour et al., 1987). These may be defined either with tabulated data or explicit functional forms such as van Genuchten (1980) and may also incorporate hysteretic effects (Kool and Parker, 1987).

\section{Dilatancy}

A robust and comprehensive mathematical framework describing the dilatant response of clay-rocks to the passage of gas is as yet unavailable. A number of approaches have been proposed using expressions describing the movement of gas through individual or multiple 
capillaries, or, discrete fractures as reviewed in Rodwell et al. (1999). Since this time some progress has been made in the representation of dilatancy. Work by Romero et al. (2012) on laboratory scale measurments lead to the development of a void ratio dependent permeability expression (Senger et al., 2014). An alternative approach proposed by Gerard et al. (2014) used an embedded pre-existing fracture in a continuum finite element model. A hydromechanical coupling between the fracture aperture, permeability and the retention properties along the fracture was included. While the solution to this model is somewhat arbitrary, dependent on the initial parameterisation of the fracture(s), a better fit to data was obtained compared to that using standard visco-capillary approaches. Other methods such as those based on Griffith theory have been proposed (Rodwell et al., 1999), in which a crack will propagate when the decrease in strain energy just balances the increase in surface energy. However, while all of these approaches have some merit, in the continued absence of appropriate phenomenological based models, outputs from these approaches should be treated with caution, in particular, when used in a predictive manner. While Darcy flow is a macroscopic phenomenon that can be understood from the fluid pressures alone, flow by dilatant pathway creation is essentially a microscopic process that couples fluid pressures to the stress-strain characteristics of the material at the pore scale. Solving such a coupled problem and scaling it up to describe the macro scale effects remains a very difficult mathematical problem.

\subsection{Literature review}

\subsubsection{Pure capillary controlled flow}

In the context of the exploration and production of natural gas/oil fields, capillary-controlled flow through the sedimentary column is generally considered to be the most relevant transport process. For high permeable reservoirs and petroleum carrier systems, oil and gas migration within water saturated rocks has been extensively analysed in the past, theoretically and experimentally (Berg, 1975; Schowalter, 1979; Dembicki and Anderson, 1989; Kleppe et al., 1997; Hirsch and Thompson, 1995). Gas transport is usually described by capillary pressure and relative permeability curves as function of water saturation (Honapour et al., 1987). Recently, research shifted more to the analysis of tight gas sandstones (Cui et al., 2009; Cluff and Byrnes, 2010) and gas/oil shales (Amann-Hildenbrand et al., 2012; Ghanizadeh 
et al., 2013). As these rocks contain much smaller pores capillary resistance to gas flow is much larger. Capillary pressures required for desaturation are much higher and the percentage of immobile water increases (Byrnes, 1996).

A comprehensive literature review on capillary gas breakthrough pressures ( $p_{c_{-} \text {brthr }}$ ) is given in (Busch and Amann-Hildenbrand, 2013). Values compiled from $\mathrm{N}_{2}$ and $\mathrm{He}$ gas breakthrough experiments cover $p_{c_{-}}$brthr-values ranging from $5 \cdot 10^{-3} \mathrm{MPa}$ for sandstones $\left(\mathrm{k} \sim 10^{-13} \mathrm{~m}^{2}\right)$ to 30 MPa for clay-rocks $\left(10^{-21} \mathrm{~m}^{2}\right)$ (Figure 3). The capillary snap-off pressure detected after spontaneous imbibition is lower than the breakthrough pressure measured on the drainage path. Both critical pressures increase with decreasing permeability.

After breakthrough, the conductivity to the gas phase after breakthrough is strongly influenced by the prevailing water content. Relative gas permeability decreases dramatically with increasing water saturations, as does the relative water permeability with decreasing water contents. As this effect becomes more pronounced for less conductive rocks, the gaswater relative permeability cross-over occurs at successively lower relative permeabilities. This effect creates water saturation regions with virtually no-flow, i.e. where relative gas/water permeabilities are less than 2\% (Byrnes, 1996; Shanley et al., 2004; Cluff and Byrnes, 2010). In clay-rich rocks, gas flow rates detected after gas breakthrough can be extremely low, corresponding to relative gas permeability coefficients down to $0.001 \%$ (Amann-Hildenbrand et al., 2013).

One effect discussed in literature is the importance of the slip-flow or Klinkenberg effect, which causes gas flow velocity and permeability to increase with decreasing mean gas pressures and decreasing pore width. In tight lithologies, which are characterised by small pores down to the nm-range, slip flow is therefore highly relevant - for dry rocks but also with increasing water saturations. Increasing slip factors are associated with those systems, where the effective pore width is reduced by water films along the pore walls (funicular flow) (Qingjie et al., 2002; Li and Horne, 2004). Decreasing slip factors are assumed to result from channel flow types, where gas and water flows through separate paths. With increasing water saturations the smallest "slip prone" pores are blocked with water and gas flow occurs in successively larger pores (Estes and Fulton, 1956; Abbas et al., 1999; Qingjie et al., 2002). From an experimental point of view, small saturation changes are very difficult to determine. Due to spontaneous water imbibition upon gas pressure release, water/gas saturation should be determined during the experiment, i.e. under external stress conditions and prevailing fluid 
pressures. Additionally, the expected quantities are likely below the detection limit of any petrophysical method. Based on imbibition gas breakthrough experiments (Residual pressure technique), Hildenbrand et al. (2002) calculated effective transport porosities to the gas phase after gas breakthrough according to a simple capillary bundle model (assuming cylindrical pores). Corresponding maximum cumulative gas filled effective transport porosity was below $0.01 \%$.

\section{Evidence for dilatancy controlled gas flow}

In initially saturated clay-rocks with extremely narrow interparticle spaces, the capillary threshold pressure required to initiate gas flow can simply be too large for the gas to be able to penetrate and de-saturate the clay (Harrington and Horseman, 1999). Indeed, Hedberg (1974), in a paper examining the role of gas to overpressure within source rocks, quotes a translation from Tissot \& Pellet (1971) in which they state "The displacement of an oil or gas phase from the centre of a finely grained argillaceous matrix goes against the laws of capillarity and is in principle impossible. The barrier can, however, be broken in one way. The pressure within the fluids formed in the pores of the source-rock increases constantly as products of the evolution of kerogene are formed. If this pressure comes to exceed the mechanical resistance of the rock, microfissures will be produced which are many orders of size greater than the natural (pore) channel of the rock, and will permit the escape of an oil or gas phase, until the pressure has fallen below the threshold which allows the fissures to be filled and a new cycle commences." This approach to the conceptualisation of immiscible gas flow succinctly sums up modern thinking on the topic and is of potential relevance to all storage and extraction industries dealing with low permeability clay based systems. Mandl and Harkness (1987) support this hypothesis and suggest that hydrocarbon migration can only occur through thick, continuous water-wet rocks of low permeability through the process of fracturing, forming what they refer to as 'dykelets'.

Several studies performed on clay materials revealed that bulk gas flow is associated with dilatant flow. In an early study, Horseman and Harrington (1994), attributed migration of gas through Boom clay to the formation of pressure induced dilatant pathways. Gas flow was linked to an approach first proposed by Lambe (1960), which recognised the importance of 'water' within the system and the ability of thin water films to conduct stress when strongly associated with the clay substrate. Horseman \& Harrington (1994) also reported intermittent 
or 'burst' type flow during gas migration experiments (Horseman \& Harrington, 1998). This combined with minimal desaturation of test samples indicated that the processes first identified for source rocks (Tissot \& Pellet, 1971) also applies to less indurated materials such as Boom clay (Volckaert et al., 1995; Horseman et al., 1996; Ortiz et al., 1996; Sen et al. , 1996). In addition, tests on compacted bentonite exhibited a critical gas breakthrough pressure of a similar order of magnitude to that of the swelling pressure (Pusch \& Forsberg, 1983; Pusch et al., 1985). Detailed studies by Horseman et al. (1997) and Horseman \& Harrington (1997) reported a series of experiments and theoretic analyses in which gas flow was accompanied by dilation of the clay fabric. Initial gas breakthrough pressures were found to be equal to or slightly in excess of total stress and again, no measureable desaturation of the material were observed, even after prolonged injection times. Horseman \& Harrington (1997) suggested that gas did not migrate through the original pore space of the water saturated bentonite and that gas permeability was a dependent variable, rather than a material property, linked to the number, width and aperture distributions of dilatant features. This hypothesis was further developed by Harrington \& Horseman (1999) summarising a series of observations on natural and engineered materials.

Studies on subsea hydrocarbon seepages (unlithified strata) suggest capillary displacement pressures are often so large, that gas pressure required to initiate flow can approach or even exceed the total stress (Clayton and Hay, 1992; Judd and Sim, 1998). Donohew et al. (2000) examined gas migration behaviour through unconfined clay pastes of varying moisture content and mineralogy under ambient conditions. In all experiments gas flow was accompanied by the creation of dilatant, preferential pathways, the morphology of which was related to the plasticity and density of the clay. Hovland et al. (2005) examined pockmark formation in the Nyegga area of the North Sea and concluded that the observed features were formed by sudden 'catastrophic' fluid flow. Post failure, micro seepages were also noted suggesting only partial self-sealing of the initial pockmark pathway occurred. The development of dilatant pathways is a well-recognised phenomenon in hydrate studies and is commonly referred to as 'grain displacing hydrate formation' (Holland et al., 2008). These authors presented a series of X-ray images showing filamental hydrate structures traversing sediment cores recovered from the Godavari Basin, India. Similar to the processes described by Donohue et al. (2000), gas flow and subsequent hydrate formation in these weak 
sediments occurred through the creation of new porosity and was not associated with flow within the original fabric of the sediment.

Further work on laboratory samples of compact bentonite (Harrington and Horseman, 2003a) clearly showed that advective gas flow was associated with the development of multiple dilatant pathways. These features were shown to vary temporally and spatially within the clay with gas pressure, total stress and pore water pressure integrally linked once the gas entry pressure had been reached. For fully water-saturated bentonite/sand plugs, gas migration was at gas pressures equal or slightly greater than the bentonite/sand swelling pressure (Liu et al., 2012).

Field scale observations at an underground research facility in Sweden confirmed these results, showing clear hydromechanical coupling during gas flow (Harrington et al. 2007; Cuss et al., 2010, 2011; Graham et al., 2012).

In recent years, significant effort has been placed on examining gas and water flow in more lithified clay-rocks (Rodwell et al., 1999; Harrington et al., 2003b, 2009, 2012a; Marschall et al., 2005; Angeli et al., 2009; Cuss \& Harrington, 2011; Skurtveit et al., 2010, 2012; Romero et al., 2012; Gerad et al., 2014; Cuss et al., 2014). Marschall et al. (2005) presented borehole data from a gas injection test within the Opalinus clay (OPA), which exhibited a hydromechanical response as recorded by extensiometers during gas injection testing. Later work by Romero et al. (2012) on laboratory scale OPA samples confirmed dilation occurred during gas flow, leading to the development of a void ratio dependent permeability expression (Senger et al., 2014). Caprock integrity studies from a number of North Sea hydrocarbon fields (Angeli et al., 2009; Harrington et al., 2009; Skurtveit et al., 2010, 2012) indicate dilatancy may be a common mechanism associated with caprock failure. Laboratory experiments injecting carbon dioxide through samples of Draupne shale show a clear increase in volume during gas flow (Angeli et al., 2009; Skurtveit et al., 2010, 2012). Simultaneous measurements of $P$ and $S$ wave acoustic velocity show a change in behaviour as $\mathrm{CO}_{2}$ moves through the sample, and is related to mechanical changes in the sample. Laboratory tests on Nordland shale samples from the Sleipner $\mathrm{CO}_{2}$ inject site were described and numerically modelled by Harrington et al., (2009). Their analysis suggested anisotropy to gas flow was greater than that of water and that gas movement primarily occurred through the development of pressure-induced pathways. 
Gerard et al. (2014) described gas flow through Callovian-Oxfordian (COx) clay-rock using an embedded fracture model. While the solution to this model is somewhat arbitrary, dependent on the initial parameterisation of the fracture(s), a better fit to laboratory data was achieved compared to that obtained using a standard visco-capillary approach.

\section{Experiments}

From the above literature review it is evident, that gas transport in initially water-saturated clay-rich rocks is very restricted. High differential (fluid, effective) pressures or concentration gradients are usually required to obtain effective flow rates that can be detected and quantified on the laboratory scale. Relatively small samples ( $\mathrm{mm}$ to $\mathrm{cm}$-range) are mounted in experimental set-ups capable of mimicking in-situ pressure and temperature conditions. Data evaluation aims at obtaining valid key-parameters, like diffusion coefficients, critical capillary entry pressures and effective gas permeability coefficients, that can be used for up-scaling to the field scale. Well-known and controlled initial and boundary conditions are a pre-requisite for proper evaluation and interpretation of the data.

\subsection{Diffusion experiments}

Diffusivities can be measured by either taking advantage of the original ("naturally occurring") gas content of rock samples or by applying gas from an external source.

In the first approach samples or rock volumes are degassed in vacuum containers or directly within the borehole. The derivation of diffusion coefficients by this procedure relies on distinct symmetry assumptions (Gómez-Hernández, 2000; Bigler et al., 2005). Diffusion coefficients can also be estimated from large-scale concentration profiles of natural tracers, such as He and $\operatorname{Ar}$ (Rubel et al., 2002; Bensenouci et al., 2011) or light hydrocarbons (Leythaeuser et al., 1980) outgassing from geological formations. Both methods have two major disadvantages: the technique is only applicable for gases that are naturally present in the clay (basically limited to $\mathrm{He}$, Ar and hydrocarbon gases) and the experimental results, obtained from the outgassing approach have to be interpreted with caution. Thus, the initial and boundary conditions are usually not known and have to be estimated. Cores start to degas immediately after or even during sampling, and they also may take up gas from the atmosphere. The uncertainties in the initial and boundary conditions directly control the uncertainty in the diffusion coefficients obtained from these procedures. 
Laboratory experiments applying external gas concentration gradients are either conducted as in- or through-diffusion techniques under well constrained boundary conditions (pressure, temperature, water saturation, gas phases and concentration potentials). Different types of through-diffusion experiments have been described in literature (Krooss and Schaefer, 1987; Rebour et al., 1997; Jacops et al., 2013). Cylindrical samples of known dimensions are usually placed into diffusion cells with gas source/sampling reservoirs on both sides. The chemical potential gradient across the sample is established by charging one compartment with the gas of interest. The gas molecules dissolve in the pore water and start to diffuse through the pore system. The gas concentration at the outlet face (sampling reservoir) or the incremental amounts of gas diffused through the sample are determined periodically and solved for effective diffusion coefficients $\left(D_{\text {eff }}\right)$ and other likely retardation processes. The pressure gradient across the sample must be maintained at (or close to) zero throughout the experiment to ensure that no convective transport (pressure-driven fluid flow) interferes with the diffusion process.

"In-diffusion" experiments are performed such that one or both faces of the water-saturated cylindrical sample plug are exposed to the gas phase at a starting time $(t=0)$ and the concentration in the adjacent reservoirs is monitored over time (Volckaert et al., 1995).

Depending on the definitions and evaluation procedures, different diffusion coefficients are obtained (e.g. effective, pore, apparent; Horseman et al., 1996). Transient diffusion curves (cumulative diffused amount of substance vs. time) recorded up to near-steady state diffusive flow (Antonov, 1970; Krooss and Schaefer, 1987), for example, contain information on retardation effects (adsorption/desorption equilibria, "chromatographic effects"). If these are not explicitly taken into account this can result in an under-estimation of the "real" steady state diffusion coefficients.

Solution functions of the differential equations for through-diffusion (e.g. diffusion through a plane parallel sheet) and in-diffusion (e.g. diffusion into a semi-infinite medium with zero initial concentration) cases under various boundary conditions are provided by Crank (1975).

\subsection{Two-phase flow experiments}

Reviews of different laboratory methods examining gas entry and breakthrough pressure measurements are found in Egermann et al. (2006) and Boulin et al. (2011, 2013). The Stepby-Step, Racking, Dynamic and Residual methods (imbibition) were compared. While the 
Racking and Dynamic methods provide values for the capillary entry pressure (in homogeneous media equal to breakthrough pressure), the Step-by-Step method also yields information on capillary gas breakthrough pressures. The Residual method yields a value for the capillary snap-off pressure on the imbibition path.

In many studies the Step-by-Step pressure increase method is used, although longer experimental durations are often involved (e.g., Thomas et al., 1968; Schowalter, 1979; Horseman et al., 1997; Harrington and Horseman, 1999; Li et al., 2005; Davy et al., 2012; Cuss et al., 2014). It allows for the detection of the capillary entry and breakthrough pressure by increasing gas pressure gradually or in distinct pressure steps. This method allows different successive fluid flow phases: water expulsion (due to gas pressure), intermittent (discontinuous) and continuous gas flows, not provided by the other methods. Several experiments were successfully performed on clay formations like Boom clay (Mol, Hades) or COx clay-rock from Bure (Harrington and Horseman, 1999; Marschall et al., 2005; Zhang et al., 2008; Harrington et al., 2012a; Cuss et al., 2014). The experiments were performed either in an open system, with analysis of the effluent (gas, water), or in a closed system, with interpretation of the pressure decay.

The Dynamic method is based on measuring the change in downstream liquid flow rate under given upstream gas pressure. After gas entry, the water outflow rate decreases as the driving pressure difference is reduced by capillary forces. The method is fast (only a few days) but requires a sufficient sample length and carefully chosen fluid pressure conditions. The experiments fail, e.g. in cases where breakthrough occurs nearly instantaneous (too high pressure differences, short sample plugs) or when differences in flow rate before and after gas entry are insufficiently small (M'Jahad, 2012). The racking method is similar. Here the water pressure is reduced on the outflow side and the pressure decay is recorded and interpreted (Boulin et al., 2011).

In contrast, the Residual approach relies on imbibition, i.e. water phase resaturation of the pore network as gas pressure decreases, to close conductive pathways (Hildenbrand et al., 2002). The experiments are performed in a closed and volume calibrated system and are interpreted through analysis of the pressure transients (Amann-Hildenbrand et al., 2013). The experiments are somewhat faster than those of the Step-by-Step approach (hours to weeks). The residual pressure difference corresponds to the final capillary "snap-off" pressure on the 
imbibition path at which the system is again dynamically sealed. It is not representative for the capillary breakthrough/threshold pressure on the drainage path (e.g. Boulin et al., 2011).

\subsection{Examples}

The experiments described below were conducted on sample sets of three different origins: Oligocene (Rupelian) Boom clay from the Belgian HADES underground laboratory (SCK-CEN), Opalinus clay from the Mont Terri Rock Laboratory (Switzerland) and COx clay-rock from the Meuse/Haute-Marne Underground Research Laboratory site (ANDRA, France). While the Boom clay is a plastic clay with no evidence of mineral transformations, the Opalinus clay and COx are consolidated clay-rocks. Their associated mineralogical, petrophysical and rock mechanical properties are summarised in Table 1 . Data variability reflects differences in mineralogical composition (i.e. clay-rich versus carbonate-rich areas) and anisotropy. Additionally, rock mechanical properties are strongly controlled by moisture content and the experimental procedure (e.g. drained vs. undrained conditions, rate of loading) (Chiarelli et al., 2003; Zhang and Rothfuchs, 2004).

\subsubsection{Example I - Through-diffusion}

Jacops et al. (2013) used the through-diffusion technique (Shackelford, 1991; Van Loon et al., 2003) to determine simultaneously the diffusion coefficients of two counter-diffusing gases in water-saturated clay. Gas compositions and concentrations were measured by gas chromatography. Several diffusion experiments with a suite of gases $\left(\mathrm{He}, \mathrm{Ne}, \mathrm{Ar}, \mathrm{Xe}, \mathrm{CH}_{4}\right.$, $\mathrm{C}_{2} \mathrm{H}_{6}$ ) were performed on two samples of Boom clay formation from the Mol-1 drilling (a drilling campaign in Mol, in the NE of Belgium). The sample plugs were oriented perpendicular and parallel to the bedding plane, respectively. The measuring temperature was $21 \pm 2^{\circ} \mathrm{C}$ and the gas pressure in both compartments $1 \mathrm{MPa}$.

The effective diffusion coefficients $\left(D_{\text {eff }}\right)$ obtained in this study are listed in Table 3. For both samples the effective diffusion coefficient decreases with increasing molar mass and size of the gas molecule. This decrease partly reflects the decrease of the diffusion coefficient in the pore fluid $\left(D_{0}\right)$ with increasing molecular mass. In addition, it is influenced by the pore geometry ("pore structure") and pore-size distribution of the transport pathways. The anisotropy of the clay samples is evident from the significant differences between effective diffusion coefficients measured perpendicular and parallel to bedding. Currently under 
investigation are (i) the influence of the microstructural properties resulting in limited accessibility of portions of the pore space (size-exclusion effects) for individual gases and (ii) adsorption effects. Samples were characterized by Mercury Injection Porosimetry (MIP), lowpressure $\mathrm{N}_{2}$ adsorption (Brunauer Emmett Teller method; BET), computed tomography (CT), micro computed tomography $(\mu-\mathrm{CT})$. Furthermore mineralogical composition, bulk density, grain-size distribution and water content were determined.

In the context of radioactive waste disposal in clay formations, reliable values for diffusion coefficients of dissolved hydrogen $\left(\mathrm{H}_{2}\right)$ are essential for a correct evaluation of the balance between generated and dissipated gas. These are required mainly to estimate the pressure build-up in storage formations over time. Diffusion experiments with hydrogen can be strongly affected by the conversion of hydrogen into methane by methanogenic microorganisms (Volckaert et al. 1995; Ortiz et al. 2002;). At the Belgian Nuclear Research Centre (SCK-CEN), a sterilisation protocol which combines i) heat treatment and gamma irradiation of the entire set-up, ii) sterilisation of the gas phase over a filter and iii) the use of a microbial inhibitor was successfully applied. First experiments conducted with this protocol yielded effective diffusion coefficients for $\mathrm{H}_{2}$ ranging from 5.4 to $7.5 \cdot 10^{-10} \mathrm{~m}^{2} \cdot \mathrm{s}^{-1}$ for Boom clay samples oriented parallel to the bedding plane. Didier (2012) studied $\mathrm{H}_{2}$ diffusion in saturated COx clay-rock and found comparable values (from $10^{-11}$ and $10^{-12} \mathrm{~m}^{2} \cdot \mathrm{s}^{-1}$ decreasing with applied P).

\subsubsection{Example II - Self-sealing vs. healing, breakthrough characteristics}

Several experiments were performed on an artificially macro-cracked and "re-sealed" COx sample in order assess its "self-healing" ability. Within about two weeks for a 10-30 mm thick sample, COx clay-rock is able to re-seal and recover a water permeability similar to intact material $\left(10^{-21} \mathrm{~m}^{2}\right)$, i.e. similar to that of plugs without macroscopically visual fractures. The self-healing capacity, where the fractured sample loses all memory regarding the macro-crack (Bock et al., 2010), should be reflected by unchanged gas breakthrough characteristics. However, in comparison to the intrinsic (water) permeability, gas breakthrough occurred at comparatively lower pressures. The breakthrough pressure was observed to be well below the total applied stress (Davy et al., 2009; Davy et al., 2013), which is related to a mixture of capillary and poro-mechanical response (Davy et al., 2013). 
The nature of gas breakthrough and its evolution with experimental time is shown in Figure 4 for a sample of $9.5 \mathrm{~mm}$ thickness. The experiment was performed at confining pressures of $12 \mathrm{MPa}$ and clearly indicates that breakthrough does not occur suddenly but rather timedependent. The initial phase is strongly non-stationary and occurs in a discontinuous manner. A first gas peak was detected at an upstream pressure $\left(p_{1}\right)$ of $2.96 \mathrm{MPa}$. At a somewhat higher gas pressure (3.6MPa) several He-peaks were sporadically recorded, with the peak frequency increasing with time ("discontinuous" flow). A similar breakthrough behaviour was shown in a repetitive experiment (after water re-saturation). However, He-peaks occurred more readily and at a higher frequency, which is likely caused by the "reactivation" of previously used pathways. The final breakthrough occurred after more than 3 hours, resulting in significant He and $\mathrm{Ar}$ concentrations (gas pressure remained unchanged, Figure 4).

The "discontinuous" or "burst type" flow type can either be related to pure capillary snap-off controlled gas passage, which requires pores of sufficiently varying size (Rossen 2000) or the intermittent opening and closure of microcracks or tensile widening of the pore system. It is likely a mixture of several processes occurring simultaneously.

\subsubsection{Example III - Dilation controlled gas flow}

Data from a series of long-term laboratory experiments examining gas flow in COx clay-rock clearly showed flow was accompanied by directly measured dilation of the original fabric at gas pressures below that of the minimum principal stress (Cuss and Harrington, 2011, 2012; Harrington et al., 2012a, 2014; Cuss et al., 2014). Figure 5 is from a triaxial test performed on COx clay-rock under in situ conditions with radial 1-3 strains measured directly at mid-plane of the sample at a 120 degree separation. The data clearly shows that gas flow is accompanied by a small, but well defined volume increase of the sample which cannot be explained by poroelastic compressibility. As outflow evolves towards steady-state, dilation increases indicating gas permeability is a dependent variable, integrally linked to the number, location and aperture distributions of conductive pathways (Harrington and Horseman, 1999).

In this example, dilatancy is manifested as a change in volumetric strain. Cuss et al. (2014) note that the observed increase in radial strain is non-uniform, suggesting localised flow occurs within the sample. Post-test measurements of sample weight and volume indicate no discernible desaturation, similar to observations by other researchers investigating clay materials (Pusch \& Forsberg, 1983; Pusch et al., 1985; Horseman \& Harrington, 1994, 1997; 
Harrington \& Horseman, 1999, 2003a; Horseman et al., 2004). Post-test visual observations of COx samples submerged in glycerol and gently heated to promoted degassing suggest that gas flow occurs through a localised network of pathways, bypassing much of the clay matrix (Harrington et al. 2014, Figure 6). Within COx samples, Harrington et al. (2012a, 2014) and Cuss et al. (2014) suggest that the coupling of gas flow and mechanical variables results in the development of significant time-dependent effects, impacting many aspects of cox samples behaviour, from gas breakthrough time to the control of deformation processes.

Similarly, images showing the traces of previous 'dilatant' features within a sample of Boom clay were presented by Harrington et al. (2012b) in which a mixture of gold and titanium oxide nano powders were injected (within a carrier gas) through the material. Post-test scanning electron microscopy imaging showed layers of clay material draped around aggregates of nano powder as well as a line of aggregates left along the trace of a sealed fracture. The dimension and shape of the aggregates along with the morphology of the fabric conclusively demonstrated that the Boom clay must have dilated to accommodate the gas flow.

\subsubsection{Example IV - Gas transport velocities (RWTH Aachen)}

In the context of numerous experiments aiming at the analysis of gas transport before and after breakthrough, it was shown that detected flow rates can often be explained by two different processes, pressure driven volume flow and/or diffusion (Hildenbrand et al., 2002; Amann-Hildenbrand et al., 2012, 2013). During the last decade, different rock types were tested, like Boom clay, Opalinus clay, strongly consolidated clay-rocks, tight sandstones and limestones. As these studies were performed for estimations of the natural (methane) or artificial (carbon dioxide) storage efficiency, all tests were performed under relatively large confining pressures and temperatures (up to $40 \mathrm{MPa}, 55^{\circ} \mathrm{C}$ ) representative for depths below $1500 \mathrm{~m}$. With the fluid (gas/water) pressures much below these pressures, hydrofracturing of the sample plugs during testing was considered unlikely and capillary controlled flow was assumed to occur within the clay-rock matrix and/or pre-existing micro fractures (Hildenbrand et al., 2002).

Figure 7 shows the pressure recordings on an Opalinus clay sample (plug length $11 \mathrm{~mm}, 10 \%$ porosity) with differentiation of the prevailing transport process: (I) The initial stage of the experiment is characterised by the displacement of remaining water. Here, pressure equilibration is controlled by pure (single-phase) water displacement, indicating an intrinsic 
permeability of $k=3 \cdot 10^{-21} \mathrm{~m}^{2}$. (II) The next phase is controlled by capillary forces. The gas phase is in contact with the sample surface at insufficiently high gas pressures and pressure equilibration stops $\left(p_{1 / 2}=\right.$ constant). This is denoted as the capillary sealing regime, where transport is diffusion controlled. The average effective diffusion coefficient is $8 \cdot 10^{-11} \mathrm{~m}^{2} \cdot \mathrm{s}^{-1}$, the corresponding nominal effective gas permeability is $6 \cdot 10^{-25} \mathrm{~m}^{2}$. (III) Gas breakthrough occurs at significant higher gas pressure $(\Delta p=12.3 \mathrm{MPa})$, resulting in increasing effective gas permeability coefficients. The decline after peak permeability $\left(5 \cdot 10^{-24} \mathrm{~m}^{2}\right)$ is characteristic for the imbibition process, where transport is gradually restricted by the back-flow of water. This decline proceeds down to flow rates associated with diffusion-controlled flow (final capillary snap-off).

Conducting experiments on samples with very low conductivity, the authors observed very long pressure equilibration times. This holds for the equilibration to the effective stress conditions as well as for the applied fluid pressure gradient. For shales and clay-rocks significant time must be given before stable (gas) flow rates are detected, which could take up to several days or even months (Thomas et al., 1968; Horseman and Harrington, 1997; Harrington and Horseman, 1999; Amann-Hildenbrand et al., 2013; Cuss et al., 2014).

\section{Final remarks and conclusions}

In 1999, Rodwell et al. stated, "there are few problems in geosciences more complex than the quantitative prediction of gas migration fluxes through an argillaceous rock formation." Whilst this statement remains true, considerable progress has been made in our understanding of the fundamental physics governing gas transport through water saturated porous materials, which is relevant to a broad range of applications, including conventional and unconventional hydrocarbons, underground gas storage, carbon capture and storage, radioactive waste disposal, landfill and other engineered liner systems. Under these auspices, numerous laboratory studies have been undertaken, providing process descriptions of gas diffusion, viscous flow and the poro-mechanical response of the material.

Diffusion of the dissolved gas phase in the pore water is generally associated with low transport efficiencies (especially over long distances) but is considered a ubiquitous process. Depending on the porous network (tortuosity, constrictions etc.) effective diffusion coefficients $\left(D_{\text {eff }}\right)$ are one to three orders of magnitude below those within the pure water phase $\left(D_{0(\mathrm{~N} 2, \mathrm{CH} 4)} \sim 10^{-9}\right.$ to $\left.10^{-8} \mathrm{~m}^{2} \cdot \mathrm{s}^{-1} ; 0-160^{\circ} \mathrm{C}\right)$. Pressure driven transport of the dissolved gas 
phase is dependent upon the intrinsic (water) permeability. In compact clay-rocks and engineered barriers, these values are generally in the nano- to sub nano-Darcy range $\left(<10^{-19}\right.$ $\left.m^{2}\right)$.

The pressure at which advective gas transport is initiated through a water saturated rock is controlled by capillary-scale forces. In weak clays, clay-rocks and shales, this can occur through the creation of pressure-induced dilatant pathways whose permeability is then dependent on the aperture, width and distribution functions of these features. Under these circumstances, standard visco-capillary models of two-phase flow (based on simple concepts of phase displacement) provide a poor representation of the underlying physics governing multi-phase flow. In compact clay-rocks and engineered barriers, gas permeability may be as low as $10^{-24} \mathrm{~m}^{2}$. At such low values, it is no longer possible to differentiate between diffusive and advective flux.

To this day, clay-rock formations (in their diversity) remain a significant challenge to the numerical modeller. While significant advances have been made, additional phenomenological relationships describing the coupling between gas flow and stress, burial history, mineralogy, petrology, geochemistry and thermal loading are required to improve model representation. The fine-grained nature of clay-rocks often results in a nano-scale control of many of these processes and parameters. In addition, the full description of heterogeneity and anisotropy and the upscaling of processes to reservoir studies remains a vibrant and challenging area of research. 


\section{Symbols and abbreviations}

\begin{tabular}{|c|c|c|}
\hline Symbol & Unit & Description \\
\hline$p$ & $\mathrm{~Pa}$ & Pressure \\
\hline $\mathrm{p}_{1}, \mathrm{p}_{2}$ & $\mathrm{~Pa}$ & Experimental up- and downstream pressure \\
\hline V & $\mathrm{m}^{3}$ & volume \\
\hline$p_{\text {mean }}=\left(p_{1}+p_{2}\right) / 2$ & $\mathrm{~Pa}$ & Fluid mean pressure \\
\hline$\Delta \mathrm{p}$ & $\mathrm{Pa}$ & Differential pressure \\
\hline$\Delta \mathrm{h}$ & $\mathrm{m}$ & Hydraulic head \\
\hline $\mathrm{p}_{\mathrm{c}}$ & $\mathrm{Pa}$ & Capillary pressure $\left(p_{c}=p_{n w}-p_{w}=\Delta p\right)$ \\
\hline$p_{w}, p_{n w}$ & $\mathrm{~Pa}$ & Pressure of the wetting and non-wetting fluid \\
\hline $\mathrm{p}_{\mathrm{c} \_ \text {entry }}$ & $\mathrm{Pa}$ & Entry pressure, drainage path, gas phase enters pore space \\
\hline $\mathrm{p}_{\mathrm{c} \_ \text {brthr }}$ & $\mathrm{Pa}$ & Breakthrough pressure, drainage path, gas out flow is detected on \\
\hline $\mathrm{p}_{\mathrm{c} \_ \text {snap-off }}$ & $\mathrm{Pa}$ & Snap-off pressure (after water imbibition) \\
\hline$\eta$ & Pa s & Dynamic viscosity \\
\hline$A$ & $m^{2}$ & Cross sectional area of the sample plug \\
\hline$d x$ & $\mathrm{~m}$ & Sample length \\
\hline $\mathrm{t}$ & s & Time \\
\hline Q & $m^{3} s^{-1}$ & Fluid flux \\
\hline$q_{i}$ & $\mathrm{~m} \mathrm{~s}^{-1}$ & Darcy velocity of phase $i$ \\
\hline k & $\mathrm{m}^{2}$ & Intrinsic (water) permeability \\
\hline$k_{\text {gas }}$ & $m^{2}$ & Apparent gas permeability (varies with $p_{\text {mean }}$ ) \\
\hline$k_{\text {gas inf }}$ & $m^{2}$ & Intrinsic, slip flow corrected, gas permeability $\left(k \sim k_{\text {gas inf }}\right)$ \\
\hline$k_{\text {eff(gas) }}$ & $m^{2}$ & Apparent effective gas permeability (two-phase flow) \\
\hline $\mathrm{k}_{\mathrm{ri}}$ & - & Relative permeability to phase $i$ \\
\hline$\phi$ & - & Porosity \\
\hline$\rho$ & $\mathrm{kg} \mathrm{m}^{-3}$ & Density \\
\hline $\mathrm{S}_{\mathrm{i}}$ & - & Saturation of phase $i$ \\
\hline$\gamma$ & $\mathrm{N} \mathrm{m}^{-1}$ & Interfacial tension \\
\hline$\theta$ & $\circ$ & Contact angle (measured in the denser fluid phase) \\
\hline r & $\mathrm{m}$ & Pore radius \\
\hline $\mathrm{C}_{\text {fluid }}$ & $\mathrm{mol} \mathrm{m}^{-3}$ & Concentration in water phase \\
\hline $\mathrm{C}_{\text {bulk }}$ & $\mathrm{mol} \mathrm{m}^{-3}$ & Bulk concentration $\left(\mathrm{C}_{\text {fluid }} * \phi\right)$ \\
\hline$D_{\text {eff }}$ & $m^{2} s^{-1}$ & Effective diffusion coefficient (related to bulk concentration gradient) \\
\hline$D_{p}$ & $m^{2} s^{-1}$ & Pore diffusion coefficient within porous medium \\
\hline$D_{\text {app }}$ & $m^{2} s^{-1}$ & Term used when considering a retardation factor $R, D_{a p p}=D_{p} / R$ \\
\hline $\mathrm{D}_{0}$ & $m^{2} s^{-1}$ & Diffusion coefficient in pure water phase \\
\hline $\boldsymbol{\delta}$ & & Constrictivity \\
\hline $\boldsymbol{\tau}$ & & Tortuosity \\
\hline $\mathrm{R}$ & & Retardation factor, retardation by physico-chemical interactions \\
\hline
\end{tabular}




\section{References}

Abbas, A., Carcasses, M., Olliver, J.-P., 1999. Gas permeability of concrete in relation to its degree of saturation. Materials and structures 32, 3-8.

Al-Bazali, T.M., Zhang, J., Chenevert, M.E., Sharma, M.M., 2009. An Experimental Investigation on the Impact of Capillary Pressure, Diffusion Osmosis, and Chemical Osmosis on the Stability and Reservoir Hydrocarbon Capacity of Shales, Offshore Europe. Society of Petroleum Engineers, Aberdeen, UK.

Al-Bazali, T.M., Zhang, J., Sharma, M.M., 2005. Measurement of the Sealing Capacity of Shale Caprocks, SPE Annual Technology Conference and Exhibition. October, 9e12, Dallas, Texas.

Amann-Hildenbrand, A., Bertier, P., Busch, A., Krooss, B.M., 2013. Experimental investigation of the sealing capacity of generic clay-rich caprocks. International Journal of Greenhouse Gas Control 123, 20-33.

Amann-Hildenbrand, A., Ghanizadeh, A., Krooss, B.M., 2012. Transport properties of unconventional gas systems. Marine and Petroleum Geology 31, 90-99.

Antonov P. L., Gladyscheva G. A., P., K.W., 1958. Die Diffusion von Kohlenwasserstoffen durch Steinsalz (Diffusion of hydrocarbons through salt rocks). Zeitschrift für Angewandte Geologie 8, 387.

Antonov, P.L., 1970. Results of the investigation of diffusion permeability of sedimentary rocks for hydrocarbon gases (in Russian). Trudy VNIIYaGG 8, 51-79.

Appold, M.S., Nunn, J.A., 2002. Numerical models of petroleum migration via buoyancy-driven porosity waves in viscously deformable sediments. Geofluids 2, 233-247.

Angeli, M., Solday, M., Skurtveit, E., Aker, E., 2009. Experimental percolation of supercritical CO2 through a caprock. Energy Procedia, 1, 3351-3358.

Bensenouci, F., Michelot, J., Matray, J., Savoye, S., Lavielle, B., Thomas, B., Dick, P., 2011. A profile of helium-4 concentration in pore-water for assessing the transport phenomena through an argillaceous formation (Tournemire, France). Physics and Chemistry of the Earth, Parts A/B/C 36, 1521-1530.

Berg, R.R., 1975. Capillary pressure in stratigraphic traps. AAPG Bulletin 59, 939-956.

Berne, P., Bachaud, P., Fleury, M., 2010. Diffusion Properties of Carbonated Caprocks from the Paris Basin. Oil Gas Sci. Technol. Rev. IFP 65, 473-484.

Bigler, T., Ilhy, B., Lehmann, B., Waber, H., 2005. Helium Production and Transport in the LowPermeability Callovo-Oxfordian Shale at the Site Meuse/Haute Marne, France, Helium Production and Transport in the Low-Permeability Callovo-Oxfordian Shale at the Site Meuse/Haute Marne, France. NAGRA, Wettingen.

Bikkina, P.K., 2011. Contact angle measurements of CO2-water-quartz/calcite systems in the perspective of carbon sequestration. International Journal of Greenhouse Gas Control 5, 12591271.

Bock, H., Dehandschutter, B., Martin, C.D., Mazurek, M., Haller, A.D., Skoczylas, F., Davy, C.A., 2010. Self-Sealing of Fractures in Argillaceous Formations in the Context of Geological Disposal of Radioactive Waste - Review and Analysis, OECD Nuclear Energy Agency report n.6184, ISBN 97892-64-99095-1.

Boisson, J.-Y., 2005. Clay club catalogue of characteristics of argillaceous rocks. Nuclear Energy Agency, NEA No. 4436, ISBN 92-64-01067-X (https://www.oecd-nea.org/rwm/reports/2005/nea4436argillaceous-catalogue.pdf), p. 72. 
Borysenko, A., Clennell, B., Sedev, R., Burgar, I., Ralston, J., Raven, M., Dewhurst, D., Liu, K., 2009. Experimental investigations of the wettability of clays and shales. J. Geophys. Res. 114, B07202.

Boudreau, P., 1996. Diagenic Models and Their Interpretation - Modelling Transport and Reactions in Aquatic Sediments. Springer, Berlin.

Boudreau, B.P., 2012. The physics of bubbles in surficial, soft, cohesive sediments. Marine and Petroleum Geology 38, 1-18.

Boulin, P.F., Bretonnier, P., Vassil, V., Samouillet, A., Fleury, M., Lombard, J.M., 2011. Entry pressure measurements using three unconventional experimental methods, Society of Core Analysts, Austin, Texas, USA, p. 12.

Boulin, P.F., Bretonnier, P., Vassil, V., Samouillet, A., Fleury, M., Lombard, J.M., 2013. Sealing efficiency of caprocks: Experimental investigation of entry pressure measurement methods. Marine and Petroleum Geology 48, 20-30.

Bossart, P., 2005. Characteristics of the Opalinus Clay at Mont Terri. http://www.mont-terri.ch, 26.

Busch, A., Amann-Hildenbrand, A., 2013. Predicting capillarity of mudrocks. Marine and Petroleum Geology 45, 208-223.

Busch, A., Alles, S., Gensterblum, Y., Prinz, D., Dewhurst, D.N., Raven, M.D., Stanjek, H., Krooss, B.M., 2008. Carbon dioxide storage potential of shales. International Journal of Greenhouse Gas Control 2, 297-308.

Bustin, A.M.M., Bustin, R.M., Cui, X., 2008. Importance of fabric on the production of gas shales. Society of Petroleum Engineers (SPE), Unconventional Gas Conference, Keystone, Colorado, USA. SPE Paper 114167.

Bruggeman, C., Maes, N., Aertsens, M., De Canniere, P., 2009. Tritiated water retention and migration behaviour in Boom clay - SFC1 level 5 report: First Full Draft. NIRAS-ONDRAF, Brussels.

Byrnes, A.P., 1996. Reservoir Characteristics of Low-Permeability Sandstones in the Rocky Mountains. The Mountain Geologist 34, 39-51.

Carles, P., Bachaud, P., Lasseur, E., Berne, P., Bretonnier, P., 2010. Confining properties of carbonated dogger caprocks (Parisian Basin) for $\mathrm{CO}_{2}$ storage purpose. Oil \& Gas Science and Technology e Revue d'IFP 65 (3), 461e472.

Chiarelli, A.S., Shao, J.F., Hoteit, N., 2003. Modeling of elastoplastic damage behavior of a claystone. International Journal of Plasticity 19, 23-45.

Clayton, C.J. and Hay, S.J., 1992. Gas migration mechanisms from accumulation to surface. Bull. Geol. Soc. Denmark, 41, 1223.

Cluff, R.M., Byrnes, A.P., 2010. Relative Permeability in Tight Gas Sandstone Reservoirs - The "Permeability Jail" Model, SPWLA 51st Annual Logging Symposium, Perth, Australia, p. 16.

Crank, J., 1975. The Mathematics of Diffusion. Clarendon Press, Oxford.

Cuss, R.J., Harrington, J., Giot, R., Auvray, C., 2014. Experimental observations of mechanical dilation at the onset of gas flow in Callovo-Oxfordian claystone. Clays in Natural and Engineered Barriers for Radioactive Waste Confinement. 400: Geological Society Special Publications: London, United Kingdom, Geological Society of London.

Cuss, R.J., Harrington, J.F., Noy, D.J., Wikman, A., Sellin, P., 2011. Large scale gas injection test (Lasgit): results from two gas injection tests. Physics and Chemistry of the Earth, 36, 1729-1742.

Cuss, R.J., Harrington, J.F., 2011. Update on Dilatancy Associated with Onset of Gas Flow in CallovoOxfordian Claystone. Progress report on test SPP_COx-2. British Geological Survey commissioned report CR/11/110, 34 pp. 
Cuss, R.J., Harrington, J.F., 2012. Final Report of FORGE WP4.1.1: The stress path permeameter experiment conducted on Callovo-Oxfordian Claystone. British Geological Survey Commissioned Report, CR/12/140. 116pp.

Cuss, R.J., Harrington, J.F., Noy, D.J., 2010. Large Scale Gas Injection Test (Lasgit) Performed at the Aspo Hard Rock Laboratory. Summary Report 2008. Svensk Karnbranslehantering AB (SKB) Technical Report TR-10-38. SKB, Stockholm, Sweden, 109 pp.

Cui, X., Bustin, A.M.M., Bustin, R.M., 2009. Measurements of gas permeability and diffusivity of tight reservoir rocks: different approaches and their applications. Geofluids 9, 208-223.

Daïan, J. F., 2010. Equilibre et transferts en milieux poreux, première partie: Etats d"équilibre, 188 p.

Davies, P.B., 1991. Evaluation of the Role of Threshold Pressure in Controlling Flow of Wastegenerated Gas into Bedded Salt at the Waste Isolation Pilot Plant (WIPP). Sandia National Laboratories, Albuquerque, New Mexico.

Davy, C.A., M'Jahad, F., Skoczylas, S., Talandier, J., 2012. Gas migration through COx claystone and implications for self-healing. Proceedings of the 5th Biot's Conference on Poromechanics (10 pages), Vienna (Austria), 10-12th July 2013.

Davy, C.A., M'Jahad, F., Skoczylas, S., Talandier, J., Ghayaza, M., 2012. Evidence of discontinuous and continuous gas migration through undisturbed and self-sealed COx claystone. $5^{\text {th }}$ International Meeting on Clays in Natural and Engineered Barriers for Radioactive Waste Management, Montpellier, 22-25th October, 2012.

Davy, C.A., M'Jahad, S. Skoczylas, F. Talandier, J., 2013. Gas migration through COx claystone and implications for self-healing, Proceedings of the 5th Biot's Conference on Poromechanics (10 pages), Vienna (Austria), 10-12 July.

Davy, C.A., Skoczylas, F., Lebon, P., Dubois, T., 2009. Gas migration properties through an argillite/bentonite interface. Applied Clay Science 42, 639-648.

Dembicki, J.R.H., Anderson, M.J., 1989. Secondary migration of oil: experiments supporting efficient movement of separate, buoyant oil phase along limited conduits. American Association of Petroleum Geologists Bulletin 73, 1018-1021.

Diamond, S., 2000. Mercury porosimetry: An inappropriate method for the measurement of pore size distributions in cement-based materials, Cem. Concr. Res. 30, 1517-1525.

Didier, M., 2012. Étude du transfert réactif de l'hydrogène au sein de l'argilite, I'Institut des Sciences de la Terre. Université de Grenoble, Grenoble, p. 275.

Donohew, A.T., Horseman, S.T., Harrington, J.F., 2000. Chapter 18: Gas entry into unconfined clay pastes between the liquid and plastic limits. In: Environmental Mineralogy. Mineralogical Society Series No. 9, London, 369-394.

Dullien, F.A.L., 1979. Porous Media: Fluid Transport and Pore Structure, 2nd ed. ed. Academic Press, New York.

Egermann, P., Lombard, J.-M., Bretonnier, P., 2006. A fast and accurate method to measure threshold capillary pressure of caprocks under representative conditions, International Symposium of the Society of Core Analysts, Trondheim, Norway, pp. 1-14.

Eseme, E., Krooss, B.M., Littke, R., 2012. Evolution of petrophysical properties of oil shales during hightemperature compaction tests: implications for petroleum ex-pulsion. Marine and Petroleum Geology 31 (1), 110-124.

Espinosa, R.M., Franke, L., 2006. Influence of the age and drying process on pore structure and sorption isotherms of hardened cement paste, Cem. Concr. Res. 36, 1969-1984. 
Estes, R.K., Fulton, P.F., 1956. GAS SLIPPAGE AND PERMEABILITY MEASUREMENTS. Transactions of the American Institute of Mining and Metallurgical Engineers 207, 338-342.

Ferrell, R.T., Himmelblau, D.M., 1967. Diffusion coefficients of nitrogen and oxygen in water. Journal of Chemical \& Engineering Data 12, 111-115.

Galle, C., 2000. Gas breakthrough pressure in compacted Fo-Ca clay and interfacial gas overpressure in waste disposal context. Applied Clay Science 17, 85-97.

Gaucher, E., Robelin, C., Matray, J.-M., Négrel, G., Gros, Y., Heitz, J.-F., Vinsot, A., Rebours, H., Cassagnabère, A., Bouche, A., 2004. ANDRA underground research laboratory: interpretation of the mineralogical and geochemical data acquired in the Callovo-Oxfordian formation by investigative drilling. Phys. Chem. Earth 29, 55-77.

Gerard, P., Harrington, J., Charlier, R., Collin, F., 2014. Modelling of localised gas preferential pathways in claystone. International Journal of Rock Mechanics \& Mining Sciences, Vol. 67, pp. 104-114.

Ghanizadeh, A., Amann-Hildenbrand, A., Gasparik, M., Gensterblum, Y., Krooss, B.M., 2013. Lithological controls on matrix permeability of organic-rich shales: An experimental study. Energy Procedia 40, 127-136.

Ghanizadeh, A., Gasparik, M., Amann-Hildenbrand, A., Gensterblum, Y., Krooss, B.M., 2014. Experimental study of fluid transport processes in the matrix system of the European organic-rich shales: I. Scandinavian Alum Shale. Marine and Petroleum Geology 51, 79-99.

Gómez-Hernández, J.J., 2000. Technical Note 2000-40: FM-C experiment: Part A) Effective diffusivity and accessible porosity derived from in-situ He-4 tests Part B) Prediction of HE-3 concentration in a cross-hole experiment.

Graham, C.C., Harrington, J.F., Cuss, R.J., Sellin, P., 2012. Gas migration experiments in bentonite: implications for numerical modelling, Mineralogical Magazine, Vol. 76(8), pp. 3279-3292.

Grathwohl, P., 1998. Diffusion in Natural Porous Media: Contaminant Transport, Sorption/desorption and Dissolution Kinetics. Kluwer Academic Publishers.

Hangx, S.J.T., Spiers, C.J., Peach, C.J., 2009. The mechanical behaviour of anhydrite and the effect of deformation on permeability development - Implications for caprock integrity during geological storage of CO2, Energy Procedia, pp. 5358-5363.

Harrington, J.F., de la Vaissière, R., Noy, D.J., Cuss, R.J., Talandier, J., 2012a. Gas flow in CallovoOxfordian clay (COx): results from laboratory and field-scale measurements. Mineralogical Magazine, 76, 3303-3318.

Harrington, J.F., Milodowski, A.E., Graham, C.C., Rushton, J.C., Cuss, R.J., 2012b. Evidence for gasinduced pathways in clay using a nanoparticle injection technique, Mineralogical Magazine, Vol. 76(8), pp. 465-474.

Harrington, J.F., Horseman, S.T., 2003a. Gas migration in KBS-3 buffer bentonite: Sensitivity of test parameters to experimental boundary conditions. Report TR-03-02. Svensk Kärbränslehantering AB (SKB), Stockholm, Sweden.

Harrington, J.F., Horseman, S.T., Noy, D.J., 2003b. Measurements of water and gas flow in Opalinus Clay using a novel guard-ring methodology. Commissioned Report CR/03/32 (Commercial - In Confidence). British Geological Survey, Environmental Protection Programme.

Harrington, J.F., Birchall, D.J., Noy, D.J., Cuss, R.J., 2007. Large Scale Gas Injection Test (Lasgit) Performed at the Aspo " Hard Rock Laboratory: Summary Report 2007. British Geological Survey Commissioned Report, CR/07/211.

Harrington, J.F., Noy, D.J., Horseman, S.T., Birchall, J.D., Chadwick, R.A., 2009. Laboratory study of gas and water flow in the Nordland Shale, Sleipner, North Sea. in M. Grobe, J. C. Pashin, and R. L. 
Dodge, eds., Carbon dioxide sequestration in geological media-State of the science: AAPG Studies in Geology 59, p. 521- 543.

Harrington, J.F., Cuss, R.C., Noy, D.J., Talandier, J., 2014. Processes Governing Advective Gas Flow in the Callovo Oxfordian Claystone (COx). Fourth EAGE Shale Workshop. DOI: 10.3997/22144609.20140026 .

Harrington, J.F., Horseman, S.T., 1999. Gas transport properties of clays and mudrocks. In. Aplin, A.C., Fleet, A.J. and Macquaker, J.H.S. (eds) Muds and Mudstones: Physical and Fluid Flow Properties. Geol. Soc. London, Spec. Pub. 158, 107-124.

Hedberg, H.D., 1974. Relationship of methane generation to undercompacted shales, diapirs and mud volcanoes. Bulletin, American Association of Petroleum Geologists, 58, 661-673.

Hildenbrand, A., Schlömer, S., Krooss, B.M., 2002. Gas breakthrough experiments on fine-grained sedimentary rocks. Geofluids 2, 3-23.

Hildenbrand, A., Krooss, B.M., Schlömer, S., Littke, R., 2003. Dynamic gas leakage through fine-grained seal lithologies, EAGE Conference 8.-11.September 2003: Fault and Top Seals. What do we know and where do we go?, Montpellier, France, pp. 0-15, 11-10.

Hildenbrand, A., Schlömer, S., Krooss, B.M., Littke, R., 2004. Gas breakthrough experiments on pelitic rocks: comparative study with $\mathrm{N} 2, \mathrm{CO} 2$ and $\mathrm{CH} 4$. Geofluids 4, 61-80.

Hirsch, L.M., Thompson, A.H., 1995. Minimum saturations and buoyancy in secondary migration. AAPG Bulletin 79.

Holland, M., Schultheiss, P., Roberts, J., Druce, M., 2008. Observed gas hydrate morphologies in marine sediments. Proceedings of the 6th International Conference on Gas Hydrates (ICGH 2008), Vancouver, British Columbia, CANADA, July 6-10, 2008.

Horseman, S.T., Higgo, J.J.W., Alexander, J., Harrington, J.F., 1996. Water, gas and solute movement in argillaceous media. Rept. No. CC-96/1 to OECD/NEA Working Group on Measurement and Physical Understanding of Groundwater Flow through Argillaceous Media. Nuclear Energy Agency, OECD, Paris. ISBN 92-64-1488-1.

Horseman, S.T., Harrington, J., Sellin, P., 1997. Gas migration in MX80 buffer bentonite. Materials Research Society Symp. Proc. 465, 1003-1010.

Horseman, S.T., Harrington, J.F., Sellin, P., 1999. Gas migration in clay barriers. Engeneering Geology 54, 139-149.

Horseman, S.T., Harrington, J.F., Sellin, P., 2004. Water and gas flow in Mx80 bentonite buffer clay. Materials Research Society, 807, 715-720.

Horseman, S.T., Harrington, J.F., 1994. Migration of repository gases in an overconsolidated clay. British Geological Survey, British Geological Survey, Technical report WE/94/7.

Horseman, S.T., Harrington, J.F., 1997. Study of gas migration in Mx80 buffer bentonite. British Geological Survey, Technical Report WE/97/7Hovland et al. (2005).

Horseman, S.T., Harrington, J.F., 1998. Evidence for threshold, Pathways and Intermittent Flow in Argillaceous Rocks, in Proceedings of a joint NEA/EC workshop on fluid flow through Faults and Fractures in Argillaceous Formations, Berne, Switzerland, 1996. NEA/OECD, Paris, pp 85-103.

Honapour, M., Koederitz, L., Harvey, H.A., 1987. Relative permeability of petroleum reservoirs, 2 ed. CRC Press, Inc., Florida.

Hovland, M., Svensen, H., Forsber, C.F., Johansen, H., Fichler, C., Fosså, J.H., Jonsson, R., Rueslåtten, H., 2005. Complex pockmarks with carbonate-ridges off mid-Norway: Products of sediment degassing. Marine Geology, 218, pp 1991-206, doi: 10.1016/j.margeo.2005.04.005. 
Hovland, M., Judd, A.G., 1988. Seabed Pockmarks and Seepages: Impact on Geology, Biology and the Marine Environment. Graham and Trotman, London.

IAEA, 2003. The long-term storage of radioactive waste: Safety and sustainability, p. 24.

IAEA, 2009. Borehole Disposal Facilities for Radioactive Waste. International Atomic Energy Agency, p. 118.

Ibrahim, M.A., Tek, M.R., Katz, D.L., 1970. Threshold Pressure in Gas Storage. Pipeline Research Committee, American Gas Association at the University of Michigan, Michigan.

Ito, D., Akaku, K., Okabe, T., Takahashi, T., Tsujia, T., 2010. Measurement of Threshold Capillary Pressure for Seal Rocks Using the Step-by-step Approach and the Residual Pressure Approach, GHGT10. Amsterdam, the Netherlands

Ishida, T. Maekawa, K. Kishi, T., 2007. Enhanced modeling of moisture equilibrium and transport in cementitious materials under arbitrary temperature and relative humidity history, Cem. Concr. Res. 37, 565-578.

Jacops, E., Volckaert, G., Maes, N., Weetjens, E., Govaerts, J., 2013. Determination of gas diffusion coefficients in saturated porous media: $\mathrm{He}$ and $\mathrm{CH} 4$ diffusion in Boom clay. Applied Clay Science 83-84, 217-223.

Judd, A.G., Sim, R.H., 1998. Shallow gas migration mechanisms in deep water sediments. Pp. 163, 73 In: Proc. S.U.T. Conference on Offshore Site Investigation and Foundation Behaviour.

Johnson, L., 2006. Gas production and transport in the near field of SF and HLW repositories in clay and crystalline rocks: processes, uncertainties and performance assessment aspects, D-No 5.1.6 of the NF-PRO project. EU Contract No F16W-CT-2003-02389., Luxembourg.

Kleppe, J., Delaplace, P., Lenormand, R., Hamon, G., Chaput, E., 1997. Representation of capillary pressure hysteresis in reservoir simulation. Proceedings - SPE Annual Technical Conference and Exhibition Sigma, 597-604.

Klinkenberg, L.J., 1941. The permeability of porous media to liquids and gases. Drilling and Production Practise, 200-213.

Kool, J.B., Parker, J.C., 1987. Development and evaluation of closed-form expressions for hysteretic soil hydraulic properties. Water Resources Research, 23, 105-114.

Krooss, B.M., Schaefer, R.G., 1987. Experimental measurements of the diffusion parameters of light hydrocarbons in water-saturated sedimentary rocks. A new experimental procedure. Organic Geochemistry 11, 193-199.

Krooss, B.M., 1988. Experimental investigation of the molecular migration of C1-C6 hydrocarbons: Kinetics of hydrocarbon release from source rocks. Organic Geochemistry 13, 513-523.

Krooss, B. M., Leythaeuser, D., 1988. Experimental measurements of the diffusion parameters of light hydrocarbons in water-saturated sedimentary rocks: II. Results and geochemical significance. Organic Geochemistry 12, 91-108.

Krooss, B.M., 1992. Diffusive loss of hydrocarbons through cap rock. Erdöl \& Kohle - Erdgas Petrochemie / Hydrocarbon Technology 45, 387-396.

Krooss, B.M., Leythaeuser, D., Schaefer, R.G., 1992a. The quantification of diffusive hydrocarbon losses through cap rocks of natural gas reservoirs-A reevaluation. AAPG Bulletin 76, 403-406.

Krooss, B.M., Leythaeuser, D., Schaefer, R.G., 1992b. The quantification of diffusive hydrocarbon losses through cap rocks of natural gas reservoirs-A reevaluation: Reply. AAPG Bulletin 76, 1842-1846.

Lambe, T.W., 1960. A mechanistic picyure of shear strength in clay. Proc ASCE Res. Conf. Shear Strength of Cohesive Soils, 550-580. 
Leythaeuser, D., Schaefer, R. G., Yükler, A., 1980. Diffusion of light hydrocarbons through near-surface rocks. Nature 284, 522-525.

Leythaeuser, D., Schaefer, R.G., Yukler, A., 1982. Role of Diffusion in Primary Migration of Hydrocarbons. AAPG Bulletin 66, 408-429.

Li, K., Horne, R.N., 2004. Experimental Study of Gas Slippage in Two-Phase Flow, SPE Western Regional Meeting. Society of Petroleum Engineers, Bakersfield, California, pp. 409-415.

Li, S., Dong, M., Li, Z., Huang, S., Qing, H., Nickel, E., 2005. Gas breakthrough pressure for hydrocarbon reservoir seal rocks: implications for the security of long-term $\mathrm{CO} 2$ storage in the Weyburn field. Geofluids 5, 326-334.

Li, X., Bernier, F., Vietor, T., P, L., 2007. TIMODAZ, Project co-funded by the European Commission under the Sixth Framework Programme (Contract No: Fl6W-CT-036449), http://www.timodaz.eu/, p. 105.

Liu, J., Davy, C.A., Skocylas, F., Talandier, J., 2012. Gas migration through compacted bentonite/sand under water and gas pressure, 5th International Meeting, Montpellier, 22-25 October 2012.

Luo, X.R., Yan, J.Z., Zhou, B., Hou, P., Wang, W., Vasseur, G., 2008. Quantitative estimates of oil losses during migration, Part II: Measurement of the residual oil saturation in migration pathways. Journal of Petroleum Geology 31, 179-190.

Mackay, D., Shiu, W.Y., 1981. A critical review of Henry's law constants for chemicals of Environmental Interest. J. Phys. Chem. Ref. Data 10, 1175-1199.

Maes, N., Salah, S., Jacques, D., Aertsens, M., Van Gompel, M., Cannière, D., Velitchkova, N., 2008. Retention of $\mathrm{Cs}$ in Boom Clay: comparison of data from and diffusion experiments on intact clay cores. Phys. Chem. Earth 33.

Marschall, P., Horseman, S., Gimmi, T., 2005. Characterisation of Gas Transport Properties of the Opalinus Clay, a Potential Host Rock Formation for Radioactive Waste Disposal, Oil \& Gas Science and Technology - IFP International Workshop. Rev. IFP, Vol. 60 (2005), No. 1, 121-139

Mandl, G., Harkness, R.M., 1987. Hydrocarbon Migration by Hydraulic Fracturing, in: Deformation of sediments and sedimentary rocks. Geol. Soc. Special Pub., Vol 29, p39-53.

M'Jahad, S., 2012. Etude de l'impact de la fissuration sur les propriétés de rétention d'eau et de transport de gaz des bétons, de l'argilite et des interfaces argilite/béton. Application au stockage géologique des déchets radioactifs. PhD thesis (in French), Ecole Centrale de Lille and Université des Sciences et Technologie de Lille, France.

Nesterow, I.I., Uschatinskij, I.N., 1972. Abschirmeigenschaften der tonigen Gesteine über Erdöl- und Erdgaslagern in den mesozoischen Ablagerungen der Westsibirischen Tiefebene (Sealing properties of claystones above petroleum and natural gas reservoirs in the Mesozoic sediments of the West Siber. Zeitschrift für Angewandte Geologie 18, 548-555.

Ortiz, L., Volcharet, G., De Canniere, P., Aertsens, M., Horseman, S.T., Harrington, J.F., Impey, M., Einchcomb, S., 1996. MEGAS - Modelling and Experiments on Gas Migration in Repository Hostrocks. Proc. EU PEGASUS Meeting at Rapolina-Terme, Italy, 14-15 June 1995. Nuclear Science and Technology Series, EUR 16746 EN, Luxembourg, 127-147.

Ortiz, L., Volckaert, G., Mallants, D., 2002. Gas generation and migration in Boom clay, a potential host rock formation for nuclear waste storage. Engineering Geology 64, 287-296.

Parker, J.C., 1989. Multiphase flow and transport in porous media. Reviews of Geophysics, 27, $311-$ 328.

Pentland, C.H., 2010. Measurements of Non-wetting Phase Trapping in Porous Media Department of Earth Science and Engineering, Royal School of Mines Imperial College London, London, p. 154. 
Prausnitz, J., Lichtenthaler, R., de Azevedo, E., 1999. Molecular Thermodynamics of Fluid Phase Equilibria. $3^{\text {rd }}$ Edition. Prentice Hall, New Jersey

Price, L.C., Blount, C.W., Mac, G., D., Wenger, L.M., 1981. Methane solubility in brines with application to the geopressured resource., Proceedings of the 5th US Gulf Coast Geopressured Geothermal Energy Conference, Baton Rouge, 1981, pp. 205-214.

Purcell, W.R., 1949. Capillary pressures - Their measurement using mercury and the calculation of permeability therefrom. Petroleum Transactions AIME 186, 39-48.

Pusch, R., Forsberg, T., 1983. Gas Migration through Bentonite Clay. SKB Technical Report 83-71. Svensk Karnbranslehanter ing AB, Stockholm, Sweden.

Pusch, R., Ranhagen, L., Nilsson, K., 1985. Gas Migration through Mx-80 Bentonite.Nagra Technical Report NTB 85-36. Nagra, Wettingen, Switzerland.

Qingjie, L., Baohua, L., Xianbing, L., Shouguo, Y., 2002. The effect of water saturation on gas slip factor by pore scale network modeling, SCA 2002 Symposium, Monterey, California.

Rebour, V., Billiotte, J., Deveughele, M., Jambon, A., le Guen, C., 1997. Molecular diffusion in watersaturated rocks: A new experimental method. Journal of Contaminant Hydrology 28, 71-93.

Rodwell, W.R., Harris, A.W., Horseman, S.T., Lalieux, P., Müller, W., Ortiz Amaya, L., Pruess, K., 1999. Gas Migration and Two-Phase Flow through Engineered and Geological Barriers for a Deep Repository for Radioactive Waste. European Commission, Report EUR19122EN.

Romero, E., Senger, R., Marschall, P., 2012. Air Injection Laboratory Experiments on Opalinus Clay. Exper- imental techniques. 3rd EAGE Shale Workshop, Barcelona, Spain, 23-25 January 2012, Results and Analyses.

Rossen, W. R., 2000. Snap-off in constricted tubes and porous media. Colloids and Surfaces A 166, pp. 101-107.

Rubel, A., Sonntag, C., Lippmann, J., Pearson, F., Gautschi, A., 2002. Solute transport in formations of very low permeability: Profiles of stable isotope and dissolved noble gas contents of pore water in the Opalinus Clay, Mont Terri, Switzerland. Geochimica Et Cosmochimica Acta 66, 1311-1321.

Sen, M.A., Horseman, S.T., Harrington, J.F., 1996. Further studies on the movement of gas and water in an overconsolidated clay: Contribution to MEGAS Phase 2 Report (PEGASUS Project). British Geological Survey, Technical Report WE/96/8 To: Commission of European Communities (CEC), Brussels.

Senger, R., Romero, E., Ferrari, A., Marschall, P., 2014. Characterization of gas flow through lowpermeability claystone: laboratory experiments and two-phase flow analyses. Geol. Soc. Special Pub. 400, doi:http://dx.doi.org/10.1144/SP400.15.

Scheidegger, A.E., 1974. The Physics of Flow through Porous Media. University of Toronto Press, Toronto.

Schlömer, S., Krooss, B.M., 1997. Experimental characterisation of the hydrocarbon sealing efficiency of cap rocks. Marine and Petroleum Geology 14, 565-580.

Schlömer, S., Krooss, B.M., 2004. Molecular transport of methane, ethane and nitrogen and the influence of diffusion on the chemical and isotopic composition of natural gas accumulations. Geofluids 4, 81-108.

Schowalter, T.T., 1979. Mechanics of secondary hydrocarbon migration in entrapment. AAPG Bulletin 63, 723-760.

Shanley, K.W., Cluff, R.M., Robinson, J.W., 2004. Factors controlling prolific gas production from lowpermeability sandstone reservoirs: Implications for resource assessment, prospect development, and risk analysis. AAPG Bulletin 88, 1083-1121. 
Stainforth, J.G., Reinders, J.E.A., 1990. Primary migration of hydrocarbons by diffusion through organic matter networks, and its effect on oil and gas generation. Organic Geochemistry 16, 361-374.

Stklyanin, Y.I., Breeva, T.F., Vasileeva, L.B., Domnina, N.A., Kotsonis, A.N., Kondratov, L.C., Antoshina, I.N., Zavyalova, L.M., Krishchenko, V.I., Shlepova, A.I., 1968. Conditions, parameters and pathways of ascending natural gas migration from oil and gas source beds and several theoretical migrational models., Trudy VNIIYaGG. Nedra, Moscow, pp. 58-131.

Stklyanin, Y.I., Litvinova, V.N., 1971. On the parameters of methane diffusion through a watersaturated core. Geologija Nefti i Gaza 15, 19-22.

Shackelford, C., 1991. Laboratory diffusion testing for waste disposal - A review. Journal of Contaminant Hydrology 7, 177-217.

Skurtveit, E., Aker, E., Soldal, M., Angeli, M., Hallberg, E., 2010. Influence of micro fractures and fluid pressure on sealing efficiency of caprock: a laboratory study on shale, Conference on Greenhouse Gas Technologies (GHGT) 10, RAI Amsterdam, The Netherlands.

Skurtveit, E., Aker, E., Soldal, M., Angeli, M., Wang, Z., 2012. Experimental investigation of CO2 breakthrough and flow mechanisms in shale. Petroleum Geoscience, Vol. 18, pp. 3-15, doi: 10.1144/1354-079311-016.

Thomas, M.M., Clouse, J., 1990a. Primary migration by diffusion through kerogen: I. Model experiments with organic-coated rocks. Geochimica et Cosmochimica Acta 54, 2775-2779.

Thomas, M.M., Clouse, J.A., 1990b. Primary migration by diffusion through kerogen: II. Hydrocarbon diffusivities in kerogen. Geochimica et Cosmochimica Acta 54, 2781-2792.

Thomas, M.M., Clouse, J.A., 1990c. Primary migration by diffusion through kerogen: III. Calculation of geologic fluxes. Geochimica et Cosmochimica Acta 54, 2793-2797.

Thomas, L.K., Katz, D.L., Tek, M.R., 1968. Threshold pressure phenomena in porous media. Society of Petroleum Engineers Journal 243, 174-184.

Tissot, B., Pellet, R., 1971. Nouvelles données sur les mécanismes de genèse et de migration du pétrole: simulation mathématique et application à la prospection. In: Proceedings of the 8 th World Petroeum Congress, Moscow, 35-46.

van Genuchten, M.Th., 1980. A closed form equation for predicting the hydraulic conductivity of unsaturated soils. Soil Science Society of America Journal, 44, 892-898.

Volckaert, G., Ortiz, L., De Canniere, P., Put, M., Horseman, S.T., Harrington, J.F., Fioravante, V., Impey, M., 1995. MEGAS - Modelling and Experiments on Gas Migration in Repository Rocks. Final Report Phase 1, Contract No. F12-CT91-0076. Nuclear Science and Technology Series EUR 16235 EN, Luxembourg.

Volckaert, G., Bernier, F., Sillen, X., Van Geed, M., Mayor, J.-C., Göbel, I., Blümling, P., Fried, B., Su, K., Similarities and Differences in the behaviour of plastic and indurated clays. $\mathrm{ftp}: / / \mathrm{ftp}$.cordis.europa.eu/pub/fp6-euratom/docs/euradwaste04pro_6-7-volckaert_en.pdf.

Volckaert, G., Bernier, F., Sillen, X., Van Geed, M., Mayor, J.-C., Göbel, I., Blümling, P., Fried, B., Su, K., 2004. Similarities and Differences in the behaviour of plastic and indurated clays, EURADWASTE '04. http://cordis.europa.eu/fp6-euratom/ev_euradwaste04_proceedings.htm, Luxembourg, 29.03.2004 - 31.03.2004., 11.

Van Loon, L., Soler, J., Bradbury, M., 2003. Diffusion of HTO, Cl-36(-) and I-125(-) in Opalinus Clay samples from Mont Terri - Effect of confining pressure. Journal of Contaminant Hydrology, 73-83.

Washburn, 1921. The dynamics of capillary flow. Physical Review 17.

Weber, C., Stanjek, H., 2012. Development of diffuse double layers in column-wicking experiments: Implications for $\mathrm{pH}$-dependent contact angles on quartz. Journal of Colloid and Interface Science 
387, 270-274.Wilke, C.R., Chang, P., 1955. Correlation of diffusion coefficients in dilute solutions. Am. Inst. Chem. Eng. J. 1, 264-270.

Wenk, H.-R., Voltolini, M., Mazurek, M., Van Loon, L.R., Vinsot, A., 2008. Preferred Orientations and Anisotropy in Shales: Callovo-Oxfordian Shale (France) and Opalinus Caly (Switzerland). Clays and Clay Minerals 56, 285-306.

Wileveau, Y., Bernier, F., 2008. Similarities in the hydromechanical response of Callovo-Oxfordian clay and Boom Clay during gallery excavation. Physics and Chemistry of the Earth, Part A: Solid Earth and Geodesy 33, 343-349.

Wilke, C.R., Chang, P., 1955. Correlation of diffusion coefficients in dilute solutions. Am. Inst. Chem. Eng. J. 1, 264-270.

Wollenweber, J., Alles, S., Busch, A., Krooss, B.M., Stanjek, H., Littke, R., 2010. Experimental investigation of the $\mathrm{CO} 2$ sealing efficiency of caprocks. International Journal of Greenhouse Gas Control 4, 231-241.

Yu, L., Weetjens, E., 2009. Summary of Gas Generation and Migration, Current State-of-the-Art. Mol, Belgium.

Zhang, T., Krooss, B.M., 2001. Experimental investigation on the carbon isotope fractionation of methane during gas migration by diffusion through sedimentary rocks at elevated temperature and pressure. Geochimica et Cosmochimica Acta 65, 2723-2742.

Zhang, C., Rothfuchs, T., 2004. Experimental study of the hydro-mechanical behaviour of the CallovoOxfordian argillite. Applied Clay Science 26, 325-336.

Zhang, C. L., Rothfuchs, T., 2008. Damage and sealing of clay rocks detected by measurements of gas permeability. Physics and Chemistry of the Earth 33, S363-S373. 


\section{Tables}

Table 1: Summary of diffusion coefficients for a variety of rock types and gases. The diffusion coefficients refer to those used in the publications.

\begin{tabular}{|c|c|c|c|c|c|c|}
\hline $\begin{array}{l}\text { Lithotype/ } \\
\text { Formation }\end{array}$ & Reference & Gas & type & Measured $\mathrm{D}\left(\mathrm{m}^{2} \cdot \mathrm{s}^{-1}\right)$ & $\phi(\%)$ & $\mathrm{T}\left({ }^{\circ} \mathrm{C}\right)$ \\
\hline Pure water & $\begin{array}{l}\text { Wilke and Chang } \\
\text { (1955), Ferrell and } \\
\text { Himmelblau } \\
\text { (1967) }\end{array}$ & - & $\mathrm{D}_{0}$ & $10^{-9}-10^{-8}$ & & $0-160$ \\
\hline Boom clay & Jacops et al. (2013) & \multirow{6}{*}{$\mathrm{He}$} & $D_{\text {app }}$ & $12.2-10^{-10}$ & 38 & 21 \\
\hline Opalinus clay & $\begin{array}{l}\text { Gómez-Hernández } \\
\text { (2000) }\end{array}$ & & $D_{\text {app }}$ & $7 \cdot 10^{-10}$ & 30 & \\
\hline Opalinus clay & Rübel et al. (2002) & & $\mathrm{D}_{\text {app }}$ & $3.5( \pm 1.3) \cdot 10^{-11}$ & & room \\
\hline $\operatorname{cox}$ & Bigler et al. (2005) & & $D_{p}$ & $2.41 \cdot 10^{-10}$ & 15.4 & 20 \\
\hline $\operatorname{cox}$ & $\begin{array}{l}\text { Rebour et al. } \\
(1997)\end{array}$ & & $D_{a p p}$ & $5 \pm 1 \cdot 10^{-11}$ & 23 & 50 \\
\hline $\begin{array}{l}\text { Toarcian/Domeri } \\
\text { an Shale }\end{array}$ & $\begin{array}{l}\text { Bensenouci et al. } \\
(2011)\end{array}$ & & $D_{p}$ & $2.4-12.7 \cdot 10^{-11}$ & $3.5-11$ & \\
\hline $\operatorname{cox}$ & Didier (2012) & $\mathrm{H}_{2}$ & $D_{p}$ & $\begin{array}{l}\sim 10^{-12}(91 \% \text { water- } \\
\text { saturated) }\end{array}$ & & 23 \\
\hline $\begin{array}{l}\text { Clay-rocks (North } \\
\text { German Basin) }\end{array}$ & \multirow[b]{3}{*}{$\begin{array}{l}\text { Schlömer and } \\
\text { Krooss (1997) }\end{array}$} & \multirow{4}{*}{$\mathrm{CH}_{4}$} & \multirow[b]{3}{*}{$D_{\text {eff }}$} & $1.0-24.4 \cdot 10^{-10}$ & $0.4-1.9$ & 150 \\
\hline $\begin{array}{l}\text { Fanglomerate } \\
\text { (North German } \\
\text { Basin) }\end{array}$ & & & & $4.46 \cdot 10^{-10}$ & 6.6 & \\
\hline $\begin{array}{l}\text { Jurassic } \\
\text { claystones and } \\
\text { siltstones } \\
\text { Smørbukk field, } \\
\text { Haltenbanken, } \\
\text { Norway }\end{array}$ & & & & $1.4 \cdot 10^{-11}-1.14 \cdot 10^{-10}$ & $0.7-6.7$ & \\
\hline Boom clay & Jacops et al. (2013) & & $\mathrm{D}_{\text {app }}$ & $2.42-10^{-10}$ & 38 & 21 \\
\hline \multirow{2}{*}{$\begin{array}{l}\text { Clay-rocks and } \\
\text { tight sandstones }\end{array}$} & \multirow{2}{*}{$\begin{array}{l}\text { Schlömer and } \\
\text { Krooss (2004) }\end{array}$} & \multirow{2}{*}{$\mathrm{N}_{2}$} & \multirow{4}{*}{$D_{\text {eff }}$} & $0.18-18.2 \cdot 10^{-11}$ & \multirow{2}{*}{$0.7-10.5$} & 90 \\
\hline & & & & $0.39-21.6 \cdot 10^{-11}$ & & \\
\hline Muderong Shale & Busch et al. (2008) & \multirow{2}{*}{$\mathrm{CO}_{2}$} & & $\begin{array}{l}3.0-4.8 \cdot 10^{-11} \\
\text { (increasing) }\end{array}$ & 20 & $45-50$ \\
\hline Emscher Marl & $\begin{array}{l}\text { Wollenweber et al. } \\
\text { (2010) }\end{array}$ & & & $\begin{array}{l}1.2-7.8 \cdot 10^{-11} \\
\text { (increasing) }\end{array}$ & 15 & $21-28$ \\
\hline
\end{tabular}


Table 2: Mineralogical, petrophysical and rock mechanical charactersitics of Boom clay, Opalinus clay and the Callovian-Oxfordian Argillite. Data were compiled from various papers: 1. Boisson (2005), 2. Bossart (2005), 3. Gaucher et al. (2004), 4. Harrington et al (2012a), 5. Maes et al (2008), 6. Marschall et al. (2005), 7. Volkaert et al., 8. Wenk et al. (2008), 9. Wileveau \& Bernier (2008), 10. Li et al. (2007), 11. Zhang and Rothfuchs (2004), 12. Chiarelli et al. (2003).

\begin{tabular}{|c|c|c|c|c|}
\hline Lithology (Location) & & $\begin{array}{l}\text { Boom clay, } \\
\text { (HADES, Mol- } \\
\text { Dessel nuclear } \\
\text { site) } \\
\end{array}$ & $\begin{array}{l}\text { Opalinus clay } \\
\text { (Mont Terri \& } \\
\text { Weinland) }\end{array}$ & $\begin{array}{l}\text { Callovian-Oxfordian } \\
\text { clay-rock } \\
\text { (Meuse / Haute- } \\
\text { Marne, Bure site) }\end{array}$ \\
\hline deposition age & [Ma] & 30 & 180 & $150-160$ \\
\hline depth below surface & {$[\mathrm{m}]$} & $190-290$ & $\begin{array}{l}1000 \text { (65-120Ma) } \\
650 \text { (at present) }\end{array}$ & $420-600$ \\
\hline Reference no. & & $1,5,7,10$ & $1,2,6,7,10$ & $1,3,4,7,8,10$ \\
\hline \multicolumn{5}{|l|}{ Mineralogy } \\
\hline Clay mineral fraction & [\%] & $23-60$ & $40-80$ & $25-60$ \\
\hline Ilite & {$[\%]$} & $10-50$ & $15-30$ & 17 \\
\hline illite/smectite mixed layer & [\%] & $5-50$ & $5-20$ & $15-36$ \\
\hline Kaolinite & {$[\%]$} & $5-20$ & $15-37$ & 2 \\
\hline Chlorite & [\%] & $0-10$ & $3-10$ & 2 \\
\hline Chlorite/smectite ML & [\%] & 0.5 & & \\
\hline Quartz & [\%] & $15-60$ & $10-32$ & $18-31$ \\
\hline K-feldspar & [\%] & $1-11$ & 0.6 & $<2$ \\
\hline Albite & [\%] & $1-10$ & 0.3 & \\
\hline Carbonates & [\%] & $1-5$ & $4-50$ & $23-44$ \\
\hline Pyrite & {$[\%]$} & $1-5$ & 1.1 & $<2$ \\
\hline iron oxides & [\%] & & 0.5 & $<2$ \\
\hline Natural organic matter & {$[\%]$} & $1-5$ & $0.6-1.5$ & $<1$ \\
\hline \multicolumn{5}{|l|}{ Petrophysical characteristics } \\
\hline bulk dry density & {$\left[\mathrm{kg} \cdot \mathrm{m}^{-3}\right]$} & 2026 & $2280-2320$ & $2250-2310$ \\
\hline grain/skeletal density & {$\left[\mathrm{kg} \cdot \mathrm{m}^{-3}\right]$} & 2650 & $2700-2770$ & 2700 \\
\hline Water content & {$[\%]$} & $19-27$ & $5-10$ & $4-8$ \\
\hline Porosity WC & [\%] & 37 & $12-21$ & $11-19$ \\
\hline Porosity (Hg or He-pycnometry) & {$[\%]$} & $36-40$ & $10-24.7$ & $10-18$ \\
\hline Specific surface $\left(\mathrm{N}_{2}-\mathrm{BET}\right)$ & {$\left[m^{2} \cdot g^{-1}\right.$} & 44 & $24-43$ & \\
\hline \multicolumn{5}{|l|}{ Rock mechanical properties } \\
\hline plastic limit & [\%] & $23-29$ & \multirow{3}{*}{$\begin{array}{l}\text { not applicable for } \\
\text { stiff materials }\end{array}$} & \multirow{3}{*}{$\begin{array}{l}\text { not applicable for } \\
\text { stiff materials }\end{array}$} \\
\hline liquid limit & {$[\%]$} & $55-80$ & & \\
\hline plasticity index & [\%] & $32-51$ & & \\
\hline Friction angle, drained (undrained) & {$\left[{ }^{\circ}\right]$} & $18-25(2-4)$ & $23-25$ & \\
\hline Cohesion, drained (undrained) & {$[\mathrm{MPa}]$} & $0.3(0.5-1.3)$ & $1-5.5$ & \\
\hline $\begin{array}{l}\text { Young's modulus, } \mathrm{E} \\
\text { normal to bedding } *\end{array}$ & {$[\mathrm{MPa}]$} & $\begin{array}{l}0.3^{(10)}, 300^{(7)} \\
2^{(1)}\end{array}$ & $2011-3500$ & $\begin{array}{l}1760-2630^{(11)}, \\
6000^{(7)}, \\
2000-8000^{(11)} \\
4000-10000^{(12)}\end{array}$ \\
\hline Poisson ratio & - & 0.125 & 0.24 & $\begin{array}{l}0.3 \\
0.1-0.25^{(12)}\end{array}$ \\
\hline Drained bulk modulus & {$[\mathrm{MPa}]$} & $200-2000$ & & $1490-2260$ \\
\hline Shear modulus & {$[\mathrm{MPa}]$} & & $800-1600$ & \\
\hline Swelling pressure, & {$[\mathrm{MPa}]$} & 0.92 & 1.2 & \\
\hline
\end{tabular}




\begin{tabular}{|l|l|l|l|l|}
\hline normal (parallel) to bedding & & & $(0.5)$ & \\
\hline $\begin{array}{l}\text { Uniaxial compressive strength, UCS } \\
\text { normal (parellel) to bedding }\end{array}$ & {$[\mathrm{MPa}]$} & 2 & $\begin{array}{l}23.1-28.1 \\
(4-17)\end{array}$ & $20-50$ \\
\hline
\end{tabular}

* References only listed individually for strongly deviating values.

Table 3: Origin of the Boom clay samples and effective diffusion coefficients measured for different gases on these samples

\begin{tabular}{|l|l|l|}
\hline & Sample 84b & Sample 127b \\
\hline Depth $\left(\mathrm{m} \mathrm{BDT}^{*}\right)$ & $233.02-233.12$ & $275.62-272.72$ \\
\hline Orientation wrt. bedding plane & $\perp$ & $/ /$ \\
\hline$D_{\text {eff }} \mathrm{He}\left(10^{-10} \mathrm{~m}^{2} \mathrm{~s}^{-1}\right)$ & 4.37 & 7.18 \\
\hline$D_{\text {eff }} \mathrm{Ne}\left(10^{-10} \mathrm{~m}^{2} \mathrm{~s}^{-1}\right)$ & 1.89 & 2.34 \\
\hline$D_{\text {eff }} \mathrm{Ar}\left(10^{-10} \mathrm{~m}^{2} \mathrm{~s}^{-1}\right)$ & 0.75 & 1.53 \\
\hline$D_{\text {eff }} \mathrm{Xe}\left(10^{-10} \mathrm{~m}^{2} \mathrm{~s}^{-1}\right)$ & 0.60 & 0.72 \\
\hline$D_{\text {eff }} \mathrm{CH}_{4}\left(10^{-10} \mathrm{~m}^{2} \mathrm{~s}^{-1}\right)$ & 0.83 & 1.42 \\
\hline$D_{\text {eff }} \mathrm{C}_{2} \mathrm{H}_{6}\left(10^{-10} \mathrm{~m}^{2} \mathrm{~s}^{-1}\right)$ & 0.46 & 0.61 \\
\hline
\end{tabular}

* reference depth is expressed as "m below drilling table". The drilling table was located at $29.73 \mathrm{~m}$ TAW (Tweede Algemene Waterpassing - Second general levelling). 


\section{Figures}

(a) Phenomenological description

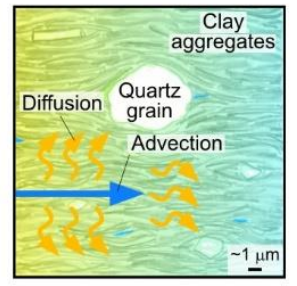

Advection \& diffusion of dissolved gas

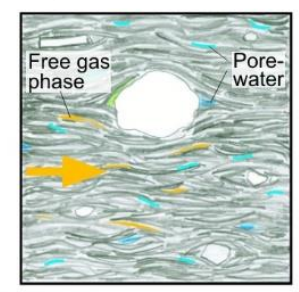

Visco-capillary flow of gas and water phase ("two-phase flow")

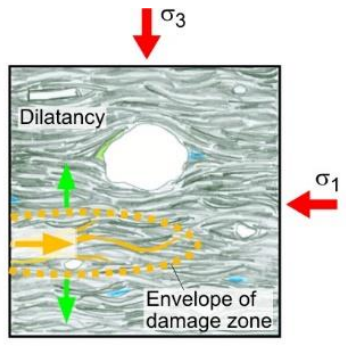

Dilatancy controlled gas flow ("pathway dilation")

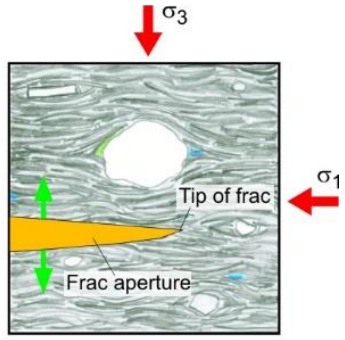

Gas transport in tensile fractures ("hydro-/gasfrac")

(b) Transport mechanisms

Single phase (liquid)
Visco-capillary two phase flow
Single phase

(gas)

(c) Geomechanical regime

\begin{tabular}{ccc|c|} 
Poro-elastic deformation & Irreversible deformation \\
& Dilatancy & $\begin{array}{c}\text { Distributed shear } \\
\text { failure }\end{array}$ & $\begin{array}{c}\text { Localised tensile } \\
\text { failure }\end{array}$ \\
\hline
\end{tabular}

(d) Barrier function of host rock

Not affected

$$
\begin{array}{cc}
\text { Dilatancy-controlled } & \begin{array}{c}
\text { Distinct fracture } \\
\text { permeability }
\end{array} \\
\text { transmissivity }
\end{array}
$$

Figure 1: Classification and analysis of gas transport processes in Opalinus clay: a) phenomenological description based on the microstructural model concept; b) basic transport mechanisms; c) geomechanical regime; and d) effect of gas transport on the barrier function of the host rock. Reprinted with permission from IFP, Figure 2 in Marschall et al., 2005). 


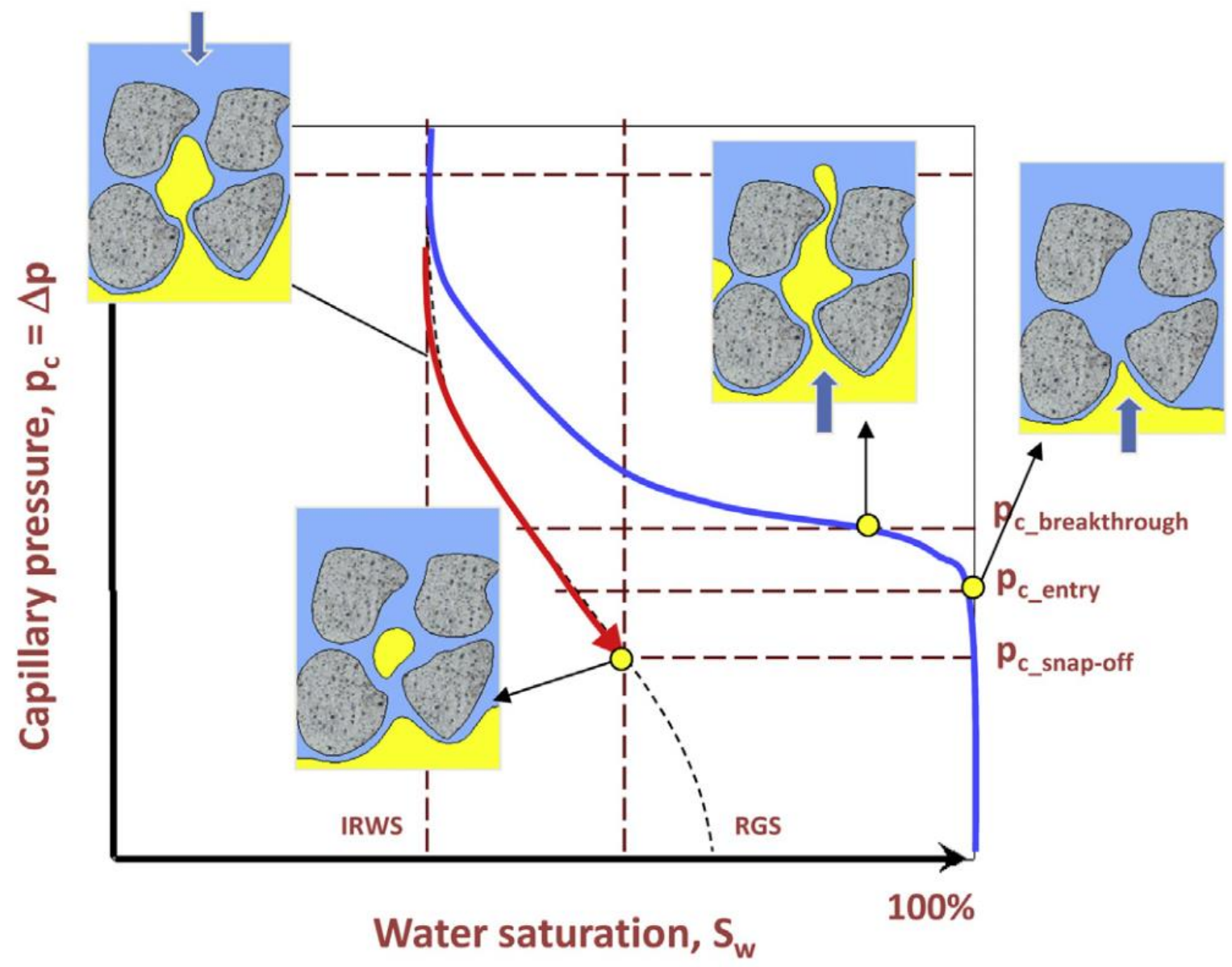

Figure 2: Conceptual sketch of capillary processes in clay-rocks. The graph shows capillary pressure $\left(\mathbf{P}_{c}\right)$ as a function of water saturation, $S_{w}$. The blue line marks the drainage path, where the non-wetting fluid displaces the wetting phase (increasing capillary pressures). The red line describes the imbibition path, where the wetting phase spontaneously re-imbibes (decreasing capillary pressures). Starting at $100 \%$ water saturation the non-wetting phase (gas) starts to displace water from the largest capillary when the entry pressure $\left(P_{c_{-} \text {entry }}\right)$ has been overcome. Upon further increase in capillary pressure the gas will break through at the outlet of the sample $\left(P_{c_{-} \text {brkth }}\right)$. Further pressure increase finally leads to the irreducible water saturation (IRWS). On the imbibition path water is imbibing into the pore system until the last inter-connecting capillary is sealed. This pressure is termed here snap-off pressure $\left(P_{c_{-} \text {snap-off }}\right)$. Reprinted with permission from Elsevier, Figure 1 in Busch and Amann-Hildenbrand (2013). 


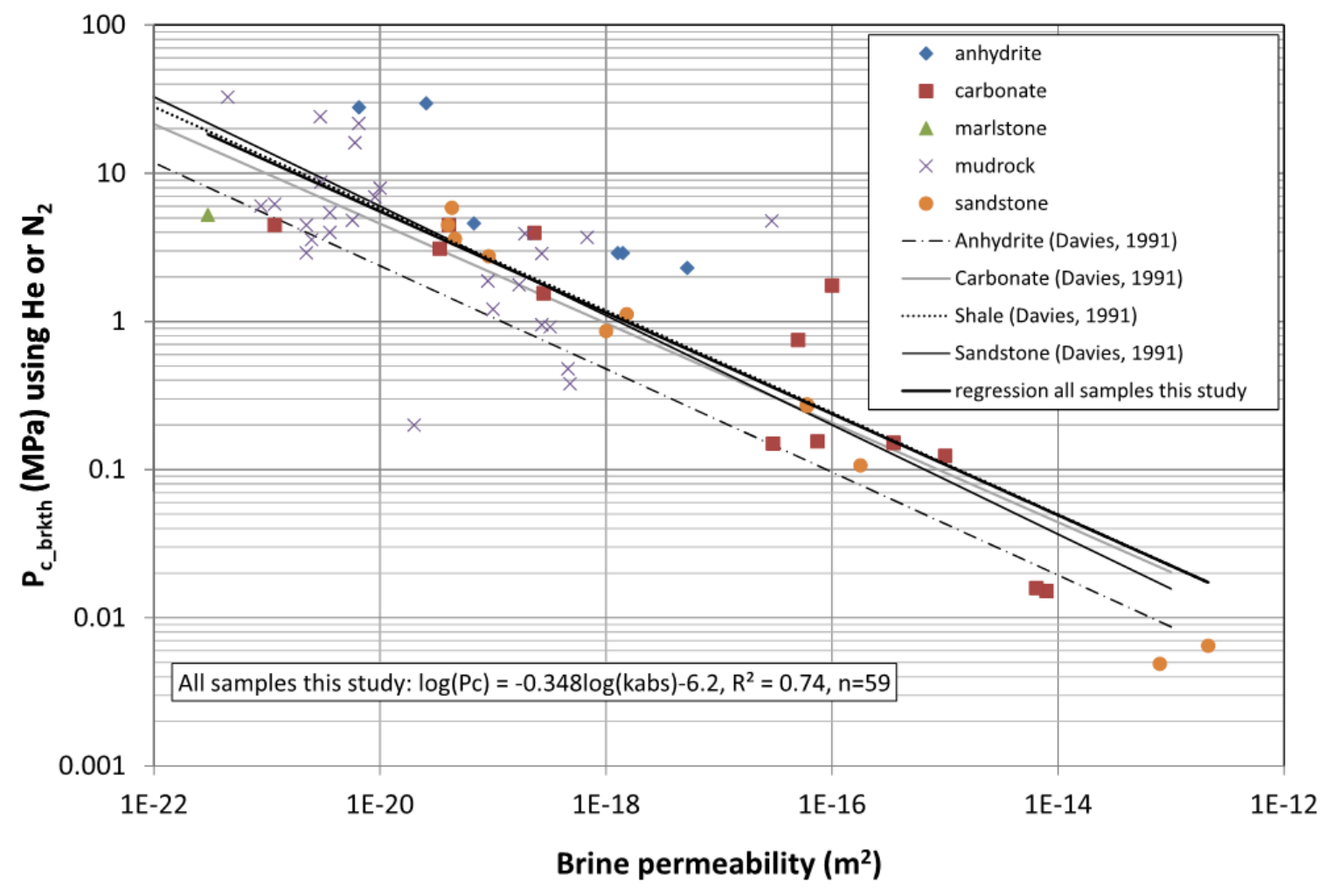

Figure 3: Drainage capillary breakthrough pressure $\left(P_{c_{-} b r k t h}\right)$ versus brine permeability on sample plugs using $N_{2}$ and Helium (from Al-Bazali et al., 2005, 2009b; Amann-Hildenbrand et al., 2013; Carles et al., 2010; Harrington and Horseman, 1999; Hildenbrand et al., 2002, 2004; Ibrahim et al., 1970; Ito et al., 2010; Li et al., 2005; Marschall et al., 2005; Purcell, 1949; Schowalter, 1979; Thomas et al., 1968). The trend lines by Davies (1991) are based on previously published datasets too, where unfortunately details of the underlying data are not given. Reprinted with permission from Elsevier, Figure 10 in Busch and Amann-Hildenbrand (2013). 


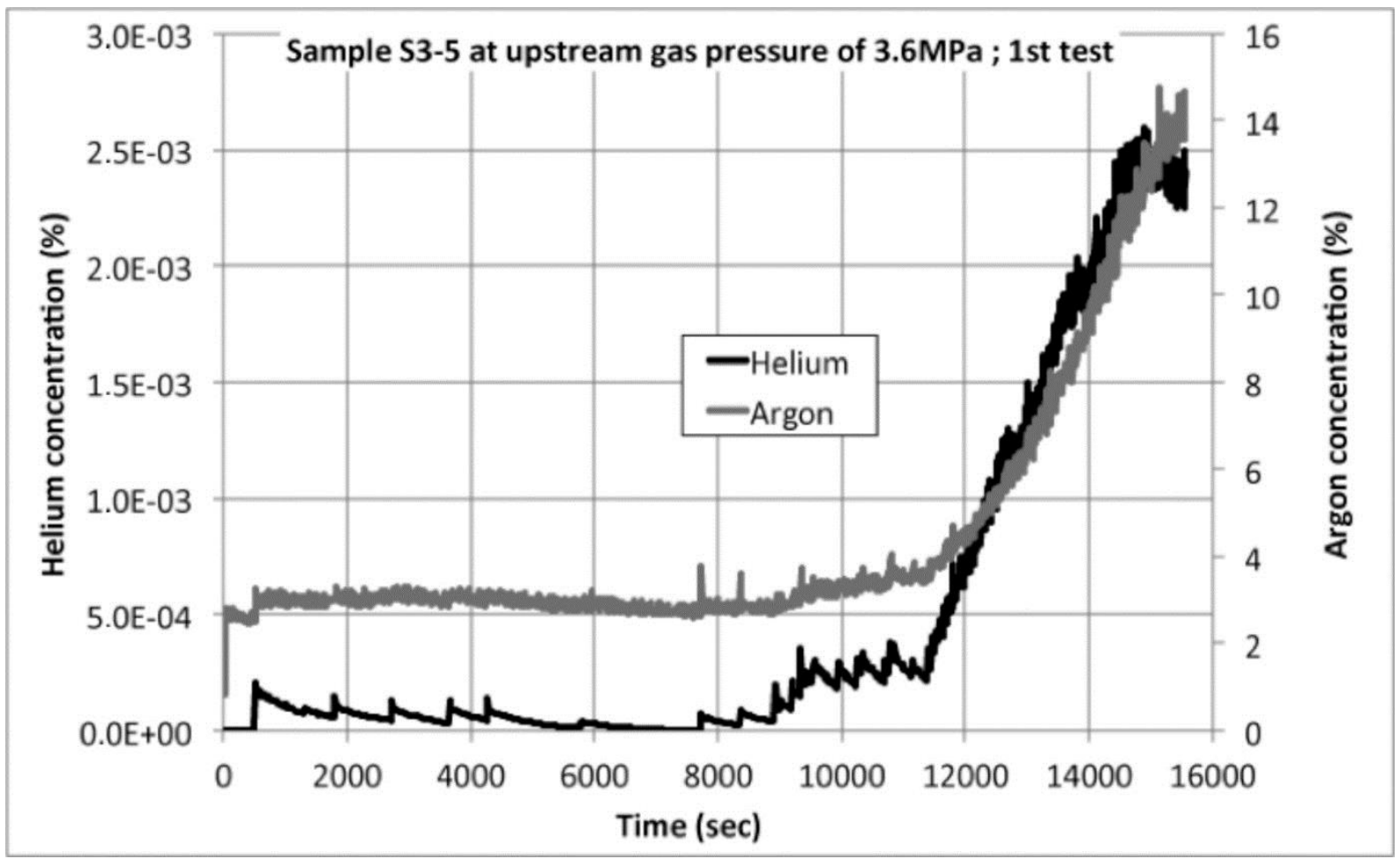

Figure 4: Second $\mathrm{He}$, Ar gas breakthrough experiment on a fractured, water re-saturated COx sample ("resealed", plug length $=9.5 \mathrm{~mm}$ ). Gas peaks frequency increases in the course of the experiment, ultimately ending in the continuous passage of helium and argon (at $12000 \mathrm{~s}$ ). The relatively higher Ar-concentration are caused by Ar-background concentrations (detection at the outflow side at atmospheric pressure). 


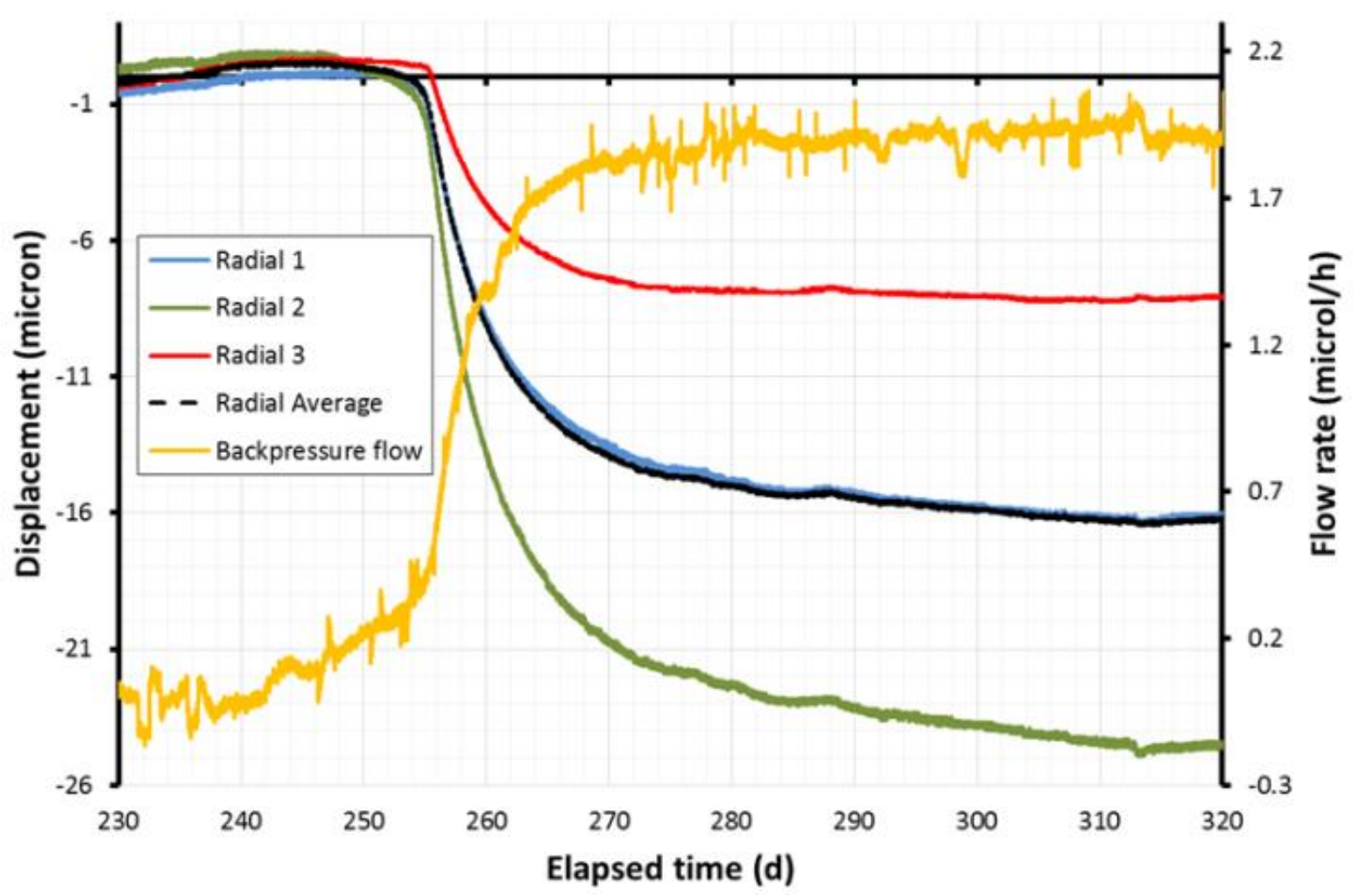

Figure 5: Strain data from triaxial test undertaken on a sample of Callovian-Oxforian clay (COx) showing coupling between sample volume and gas outflow. Negative strain (radial 1-3 \& average) indicates dilation of the sample. 


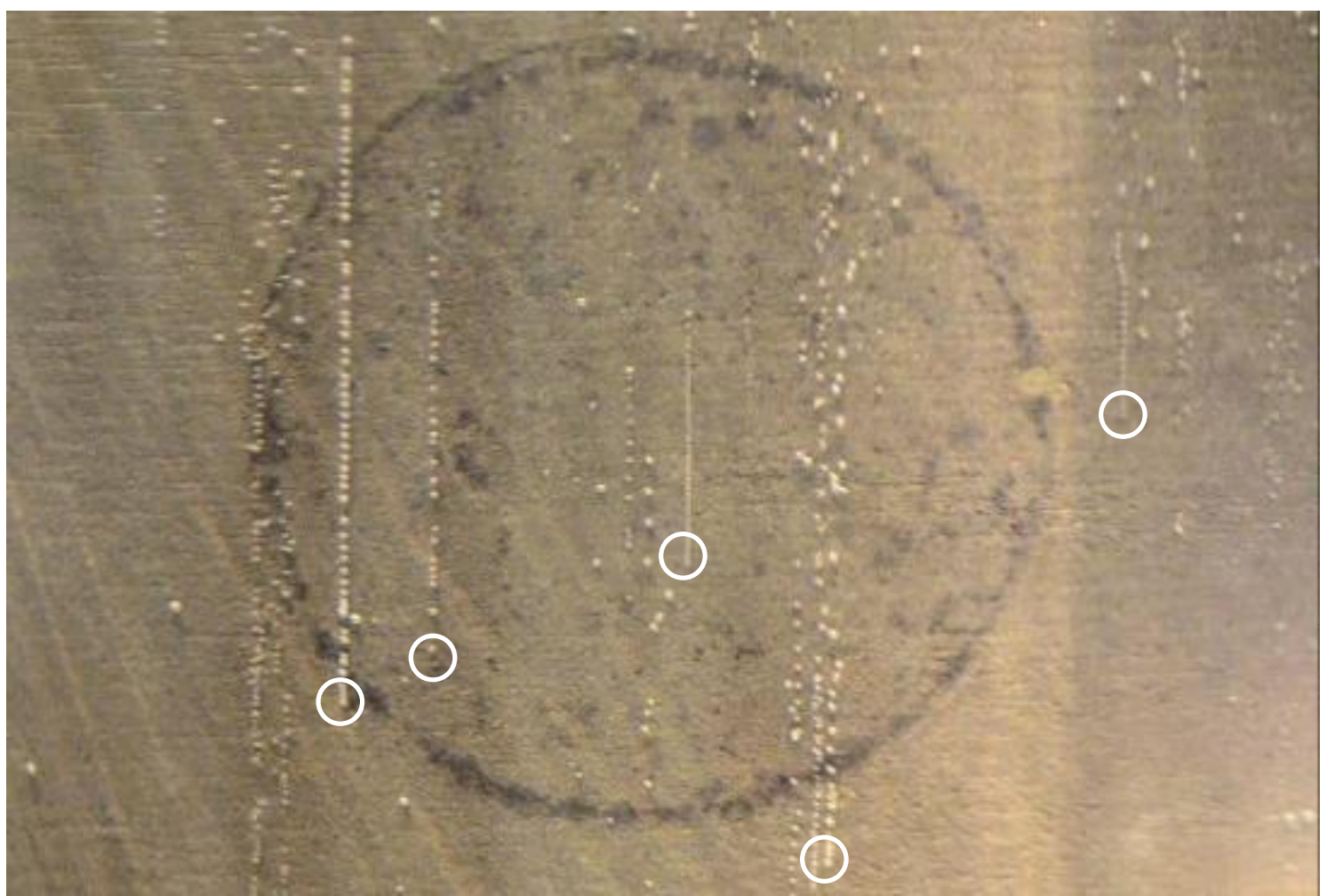

Figure 6: Post-test degassing of a COx sample (downstream end) submerged and gently heated in glycerol, indicating localised gas flow through the clay-rock. The dark staining is a residual imprint of the backpressure filter. Bubble streams are seen to emerge from multiple locations, five of which are highlighted by the white circles (Figure 8 in Harrington et al., 2012a).

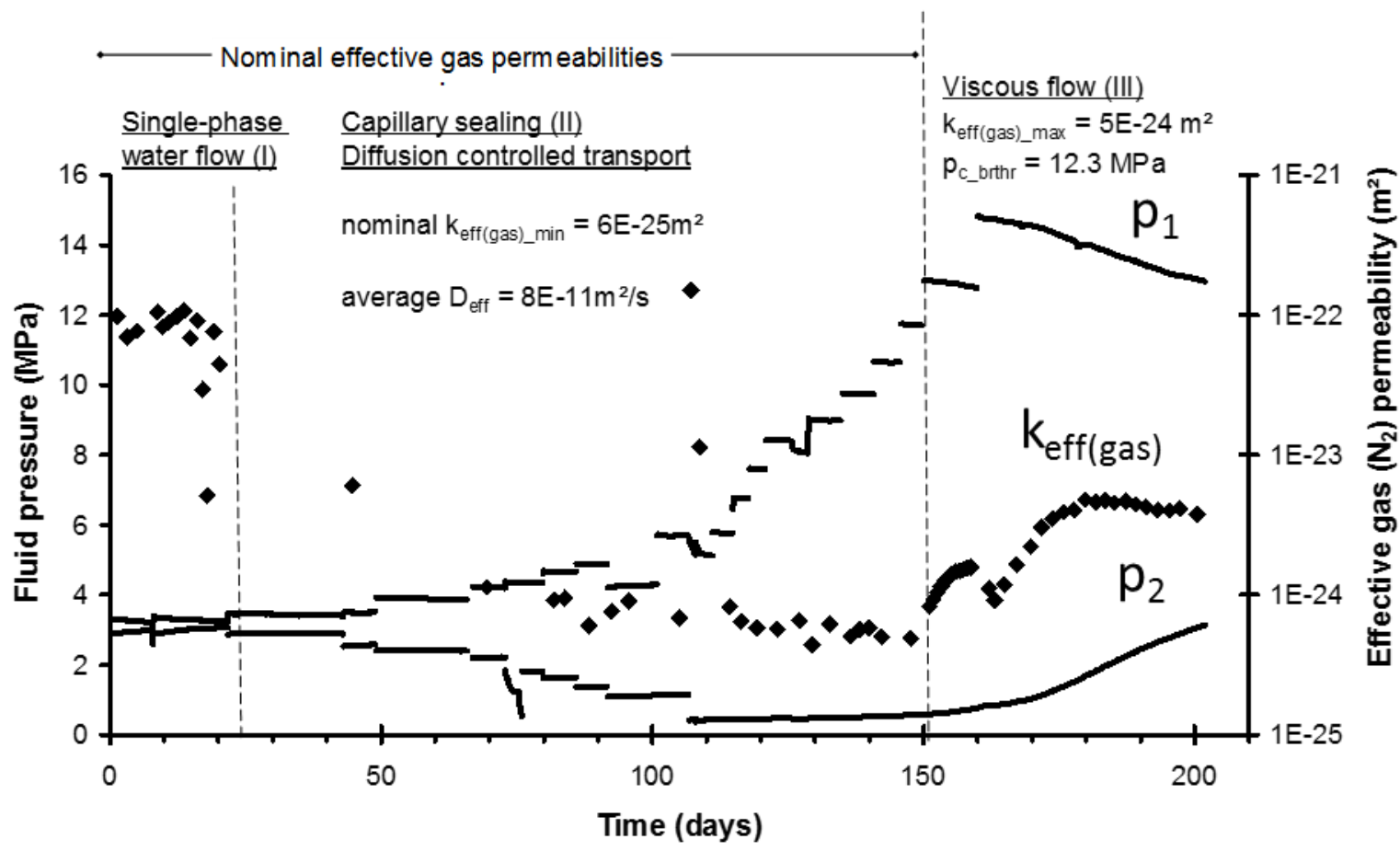


Figure 7: Gas $\left(\mathrm{N}_{2}\right)$ breakthrough experiment performed on an Opalinus clay at a confining pressure of 30MPa and $45^{\circ} \mathrm{C}$. The maximum fluid (gas) pressure on the high pressure, $p_{1}$, side is $14 \mathrm{MPa}$. The differential pressure was step-wise increased until the pressure in the downstream pressure compartment clearly increased, which was interpreted as the onset of viscous gas flow (III). After that, the flow rates increased up to an effective gas permeabilities of only $5 \cdot 10^{-24} \mathrm{~m}^{2}$ (diamonds). Mass transport prior to breakthrough is attributed to pure (I) water displacement and (II) diffusion - here the term "nominal effective gas permeability" is used. 